\title{
A knock-in/knock-out mouse model of HSPB8-associated distal hereditary motor neuropathy and myopathy reveals toxic gain-of-function of mutant Hspb8
}

\author{
Delphine Bouhy ${ }^{1} \cdot$ Manisha Juneja $^{1} \cdot$ Istvan Katona $^{2} \cdot$ Anne Holmgren $^{1} \cdot$ Bob Asselbergh $^{3} \cdot$ Vicky De Winter $^{1}$. \\ Tino Hochepied ${ }^{4,5} \cdot$ Steven Goossens $^{5,6,7} \cdot$ Jody J. Haigh $^{5,10}$ • Claude Libert ${ }^{7}$ - Chantal Ceuterick-de Groote ${ }^{8}$. \\ Joy Irobi ${ }^{9} \cdot$ Joachim Weis $^{2} \cdot$ Vincent Timmerman ${ }^{1}$
}

Received: 19 May 2017 / Revised: 20 July 2017 / Accepted: 25 July 2017 / Published online: 5 August 2017

(c) The Author(s) 2017. This article is an open access publication

\begin{abstract}
Mutations in the small heat shock protein B8 gene (HSPB8/HSP22) have been associated with distal hereditary motor neuropathy, Charcot-Marie-Tooth disease, and recently distal myopathy. It is so far not clear how mutant HSPB8 induces the neuronal and muscular phenotypes and if a common pathogenesis lies behind these diseases. Growing evidence points towards a role of HSPB8 in chaperone-associated autophagy, which has been shown to be a determinant for the clearance of poly-glutamine aggregates in neurodegenerative diseases but also for the maintenance of skeletal muscle myofibrils. To test this hypothesis and better dissect the pathomechanism of mutant HSPB8, we generated a new transgenic mouse model leading to the expression of the mutant protein (knock-in lines) or the lossof-function (functional knock-out lines) of the endogenous
\end{abstract}

Electronic supplementary material The online version of this article (doi:10.1007/s00401-017-1756-0) contains supplementary material, which is available to authorized users.

Vincent Timmerman

vincent.timmerman@uantwerpen.be

1 Peripheral Neuropathy Research Group, Department of Biomedical Sciences and Institute Born Bunge, University of Antwerp, Universiteitsplein 1, 2610 Antwerpen, Belgium

2 Institute of Neuropathology, RWTH Aachen University Hospital, Aachen, Germany

3 VIB Center for Molecular Neurology, University of Antwerp, Antwerpen, Belgium

4 Transgenic Mouse Core Facility, VIB Inflammation Research Center, Gent, Belgium

5 Department of Biomedical Molecular Biology, Ghent University, Gent, Belgium

6 Cancer Research Institute Ghent (CRIG), Ghent University, Gent, Belgium protein Hspb8. While the homozygous knock-in mice developed motor deficits associated with degeneration of peripheral nerves and severe muscle atrophy corroborating patient data, homozygous knock-out mice had locomotor performances equivalent to those of wild-type animals. The distal skeletal muscles of the post-symptomatic homozygous knock-in displayed Z-disk disorganisation, granulofilamentous material accumulation along with $\mathrm{Hspb} 8, \alpha \mathrm{B}$-crystallin (HSPB5/CRYAB), and desmin aggregates. The presence of the aggregates correlated with reduced markers of effective autophagy. The sciatic nerve of the homozygous knock-in mice was characterized by low autophagy potential in presymptomatic and Hspb8 aggregates in post-symptomatic animals. On the other hand, the sciatic nerve of the homozygous knock-out mice presented a normal morphology and their distal muscle displayed accumulation of abnormal mitochondria but intact myofiber and Z-line organisation. Our data, therefore, suggest that toxic gain-of-function

7 VIB Inflammation Research Center, Ghent University, Gent, Belgium

8 Laboratory of Neuromuscular Pathology, Institute Born-Bunge and Translational Neurosciences, University of Antwerp, Antwerpen, Belgium

9 Neurofunctional Genomics, Biomedical Research Institute (BIOMED), Hasselt University/Transnational University Limburg, School of Life Sciences, Diepenbeek, Belgium

10 Present Address: Mammalian Functional Genetics Laboratory, Division of Blood Cancers, Australian Centre for Blood Diseases, Monash University, Melbourne, VIC 3004, Australia 
of mutant Hspb8 aggregates is a major contributor to the peripheral neuropathy and the myopathy. In addition, mutant Hspb8 induces impairments in autophagy that may aggravate the phenotype.

Keywords Peripheral neuropathy $\cdot$ Myofibrillar myopathy $\cdot$ HSPB $8 \cdot$ Autophagy

\section{Introduction}

Distal hereditary motor neuropathies (dHMN) are a group of clinically and genetically heterogeneous disorders characterized by the degeneration of motor axons in the peripheral nervous system [35]. In dHMNtype II, lower motor neurons are typically involved, whereas sensory functions are mainly spared and symptoms can rapidly evolve into weakness of lower distal muscles and severe neurogenic muscular atrophy [77]. We and others identified two dominant missense mutations targeting the same lysine 141 residue, the K141N (Lys141Asn) and K141E (Lys141Glu) in the highly conserved $\alpha$-crystallin domain of the small heat shock protein B8 gene (HSPB8/HSP22) causative of dHMNtype II [24, $43,76,77]$. Identical and additional mutations at Lys141 were associated with Charcot-Marie-Tooth disease type 2L (CMT2L), which differs from dHMN by its sensory involvement [55, 74], and recently with distal myopathy [25, 34]. In the latter case, patients with K141E or frameshift mutation in HSPB8 presented a progressive myopathy associated with myofibrillar network disruption and rimmed vacuolar pathology reminiscent of myofibrillar myopathy (MFM) hallmarks [17, 47]. Despite the growing interest in the biological role of HSPB8 and the consequence of its mutation, the pathogenesis of the neuromuscular phenotype in patients with mutant HSPB8 remains to be solved.

The HSPB 8 is one of the ten members of the small heat shock protein family (sHSP), a group of molecular chaperones known to be up-regulated under heat stress or toxic stress. All the members of the sHSP family share a highly conserved $\alpha$-crystallin domain and a remarkable ability to form large dynamic oligomers whose composition and stoichiometry regulate their function [36]. The sHSPs participate in the proteome integrity by binding to the hydrophobic regions of misfolded and non-native proteins in stressful conditions. Besides their canonical function in proteostasis, sHSPs have been involved in an increasing number of cellular functions in stress and physiological conditions such as cellular differentiation and proliferation, translation, oxidative stress regulation, cytoskeleton stabilisation, apoptosis, and autophagy $[1,3$, 19, 33, 39, 59, 86]. Interestingly, mutations in HSPB 1 and $\alpha B$-crystallin, two other members of the same sHSP family, have also been associated with inherited peripheral neuropathies [11, 24, 27, 48, 63, 68], and distal myopathy, respectively $[28,53,82]$. The reason why mutations in those ubiquitous chaperones affect specifically peripheral nerves and muscle is unclear. A number of papers published by Carra et al. demonstrated how HSPB8 participates in aggregates clearance through its interaction with the Beclin2 Associated Anathogen 3 (BAG3) complex [13-15]. Dimers of HSPB8 bind to the co-chaperone BAG3 which allow the ubiquitination of the to-be-cleared substrate via its interaction with the heat shock protein 70 (HSP70) and CHIP (carboxyl terminus of HSC70-interacting protein) complex. Once ubiquitinated, the substrate is identified by sequestosome-1 (SQSTM1), also known as the ubiquitin-binding protein p62, and engulfed by the autophagosome for degradation in a process called macroautophagy. The involvement of the HSPB8/BAG3 complex in the clearance of aggregates associated with neurodegenerative diseases such as Huntington's disease, frontotemporal dementia, amyotrophic lateral sclerosis, and spinobulbar muscular atrophy supports a key role of this chaperone-mediated autophagy in the maintenance of neurons in general and motor neurons in particular [14, $16,22,65]$. Interestingly, the $\mathrm{K} 141 \mathrm{~N}$ and $\mathrm{K} 141 \mathrm{E}$ missense mutations in HSPB 8 associated with dHMN and myopathy reduce the ability of HSPB8 to bind to BAG3, and impair the degradation of aggregates via autophagy in vitro and in vivo $[12,50]$. The interaction of the HSPB8/BAG3 complex with HSC70 (the cognate form of HSP70) and p62 (p62/SQTM1) is also essential in skeletal muscle maintenance where it promotes the degradation of the actin-crosslinking protein Filamin $\mathrm{C}$ damaged by muscle contraction $[2,80]$. Accordingly, mutation or deficiency in p62, BAG3, and HSPB8 has been shown to induce distal myopathy associated with rimmed vacuole and myofibrillar disorganisation on muscle biopsy [10, $25,34,40,49,71]$. New roles are also emerging for the HSPB8/BAG3 complex in actin dynamics, spindle orientation, mitosis, and stress granule regulation [30, 31, 81] and for HSPB 8 in mitochondria oxidative phosphorylation and membrane potential maintenance $[42,52,54$, 62]. In addition, mutations in HSPB 8 can, in vitro, induce HSPB8 aggregation [42], increase its binding to the RNA helicase Ddx20 [73], and several heat shock proteins [29, 42], as well as impair the ability of primary neurons to form neurites in vitro [41]. It is, therefore, difficult to pinpoint to a main function altered by mutant HSPB8 which could be responsible for the neuropathic and myopathic phenotypes. In this study, we developed a new transgenic mouse model using the endogenous Hspb8 promoter that allowed the generation of mutant Hspb8 knock-in (KI) lines as well as Hspb8 functional knock-out (KO) lines to achieve better understanding of HSPB8-related neuromuscular pathogenesis. 


\section{Materials and methods}

\section{Ethics statement}

All mouse experiments were carried out with approval of the Ethical Committee for Laboratory Animals (University of Antwerp). Mice were housed under the care of the Animal Facility Interfaculty Unit, which is accredited by the Association for Assessment and Accreditation of Laboratory Animals. All experiments were performed on adult female $\mathrm{Hspb}^{\mathrm{K} 141 \mathrm{~N} / \mathrm{K} 141 \mathrm{~N}}$ (knock-in, KI); Hspb8 ${ }^{-/-}$(knock-out, KO); and $\mathrm{Hspb}^{+/+}$(wild type, WT) mice; except when otherwise stated.

\section{Generation of the HspB8 targeting vector}

A single targeting vector was generated to produce $\mathrm{Hspb} 8^{\mathrm{K} 141 \mathrm{~N}} \mathrm{KI}$ and $\mathrm{Hspb} 8 \mathrm{KO}$ transgenic mouse lines. Briefly, the BAC clone bMQ-191J17 (Geneservice, Cambridge, UK) containing the full length mouse $H s p b 8$ genomic DNA was used as starting material. The Neomycin (Neo) selection gene, floxed by Flp recombinase target $(F R T)$ sites and followed by a loxP site, was retrieved from a pPGK-loxPFRT-Neo-FRT plasmid (gift from D. J. van Hengel, VIB Department for Molecular Biomedical Research, Ghent). Through PCR, a loxP site upstream of exon 2 was added, as well as specific restriction sites to allow further cloning, Southern blot analysis, and genotyping. The restriction enzymes used were AatII, BamHI, EcoRV, HindIII, MluI, NotI, SacII, SexAI, and XhoI (New England Biolabs, Ipswich, MA, USA). In a first step, all fragments were cloned individually in a pCR2.1_TOPO vector (Life Sciences, Little Chalfont, UK). Next, in vitro mutagenesis was performed to insert the $\mathrm{K} 141 \mathrm{~N}$ (c.423 G > C) mutation in the exon 2 of the $H s p b 8$ gene. The final targeting vector contained (1) the K141N point mutation in exon 2 of the Hspb8 gene; (2) the Neo gene cassette, downstream of $h s p b 8$ exon 2; (3) two loxP sites to allow the excision of exon 2 and the Neo cassette to generate a functional Hspb8 KO mouse line.

\section{Chimeric mouse generation and breeding}

The linearized targeting vector was electroporated in G4 embryonic stem cells (G4 ES, Mount Sinai, Toronto, CA) [32]. Clones were selected for resistance to neomycin and screened for correct targeting by PCR, Multiplex Amplicon Quantification (Multiplicom, Antwerp, Belgium) and Southern blot. Correctly targeted cells (from 29/A10 ES cell clone) were aggregated with outbred Swiss morula, which were then implanted into pseudopregnant Swiss mice. The ES cell manipulations and transgenic mouse generation were performed by T.H., S.G., and J.J.H. This led to the generation of a transgenic line having the K141N mutation integrated in the exon 2 of the endogenous mouse $H s p b 8$ gene. Transgenic mice from the F2-generation were backcrossed on a C57BL/6J genetic background. Homozygous $\mathrm{Hspb} 8^{\mathrm{K} 141 \mathrm{~N} / \mathrm{K} 141 \mathrm{~N}}$, heterozygous $\mathrm{Hspb} 8^{\mathrm{K} 141 \mathrm{~N} /+}$ transgenic mice, and wild-type littermates were obtained by crossing heterozygous $\mathrm{Hspb} 8^{\mathrm{K} 141 \mathrm{~N} /+}$ lines. Heterozygous $\mathrm{Hspb} 8^{\mathrm{K} 141 \mathrm{~N} /+}$ lines were also crossed with Sox2-Cre lines to generate functional $\mathrm{Hspb} 8 \mathrm{KO}$ mice after exon 2 excision by Cre-lox recombination and obtain heterozygous $\mathrm{Hspb}^{-/+}$, homozygous $\mathrm{Hspb}^{-/-}$, and wild-type littermates.

\section{PCR analyses and sequencing}

ES screening and genotyping of transgenic animals was performed by PCR on a Veriti 96 well Thermal Cycler (Applied Biosystems, Thermo Fisher Scientific Inc., Waltham, MA, USA) using 4 primer sets. The primers for the distinction of the WT and KI allele were as follows: LoxP_Fw, ATCTTG AAGCATTGAAGCAAGG (forward primer) and LoxP_Rv, TATTGAAATACGGACTGAGTGGG (reverse primer). The PCR reaction resulted in a 188 bp fragment corresponding to the WT allele and/or a $235 \mathrm{bp}$ fragment corresponding to the KI allele. The $\mathrm{KO}$ allele was detected by an amplicon of 390 bp using the following primers: KO_Fw CAGCATCTT GAAGCATTGAAGC and KO_Rv AGCACAAGGGTCCAT ATACTCCAG. The primers for the detection of the CRE recombinase transgene were CRE5 ATGTCCAATTTA CTGACCG and CRE3 CGCCGCATAACCAGTGAA. The genotype was validated by sequencing exon 2 of the $H s p b 8$ mouse gene after amplification by PCR using the following primers: Hspb8_exon2_Fw GGAAGTTAGGGAGCAGGT GTCC and Hspb8_exon2_Rv GGAAGTTAGGGAGCA GGTGTCC. The PCR contained standard 10× PCR buffer, $50 \mathrm{mM} \mathrm{MgCl}_{2}$ (for the $\mathrm{KO}$ and Cre PCR) or $1 \mathrm{M}$ betain (for Exon2 and LoxP PCR), $10 \mathrm{mM}$ dNTPs, $0.10 \mu \mathrm{M}$ of each primer, and 1 unit of Platinum Taq Polymerase (Clontech Laboratories, Mountain View, CA, USA) for the KO and Cre PCR. We used Titanium Taq polymerase (Clontech Laboratories, Mountain View, CA, USA) to perform the Exon 2 and LoxP PCR on $100 \mathrm{ng}$ genomic DNA isolated from mouse ear or tail biopsies. The PCR conditions for amplification of Exon 2, LoxP, and $\mathrm{KO}$ were as follows: initial denaturation for $5 \mathrm{~min}$ at $95^{\circ} \mathrm{C}$ followed by 35 cycles of $45 \mathrm{~s}$ denaturation at $95^{\circ} \mathrm{C}, 45 \mathrm{~s}$ primer annealing at $68^{\circ} \mathrm{C}$ (for the Exon2 PCR), $66{ }^{\circ} \mathrm{C}$ (for the LoxP PCR), or $60{ }^{\circ} \mathrm{C}$ (for the KO PCR) and a final extension of 5 min at $68^{\circ} \mathrm{C}$ (for the Exon 2 and Lox PCR) or $72{ }^{\circ} \mathrm{C}$ (for the KO PCR). The Cre PCR condition was as follows: initial denaturation for $2 \mathrm{~min}$ at $95{ }^{\circ} \mathrm{C}$ followed by 40 cycles of $30 \mathrm{~s}$ at $95^{\circ} \mathrm{C}, 1 \mathrm{~min}$ at $58^{\circ} \mathrm{C}$, and $1 \mathrm{~min}$ at $72{ }^{\circ} \mathrm{C}$, and a final extension of $10 \mathrm{~min}$ at $72{ }^{\circ} \mathrm{C}$. PCR products were detected on 2 or $3 \%$ (for the LoxP PCR product) agarose gels. The genotype was validated by 
sequencing the exon 2 of the mouse $H s p b 8$ gene. Sequencing was performed on purified DNA using the BigDye ${ }^{\circledR}$ Terminator v3.1 Cycle Sequencing Kit (Applied Biosystems, Thermo Fisher Scientific Inc., Waltham, MA, USA) and separated on an ABI3730xl DNA Analyser (Applied Biosystems, Thermo Fisher Scientific Inc., Waltham, MA, USA). Resulting DNA sequences were aligned and analysed with the CLC Main workbench software.

\section{Behavioural phenotype of the mice}

All behavioural experiments were carried out according to the recommendation of the Ethical Committee for Laboratory Animals (University of Antwerp). The motor and sensory functions were assessed at 3, 6, 9, 12, and 18 months of age in adult female mice. The behavioural assessment was performed by an experimenter blind to the mice genotype.

\section{Tail suspension test}

Each mouse was lifted up by the tail at a height of approximately $20 \mathrm{~cm}$ and the hind limb spreading reflex versus clasping behaviour was assessed.

\section{Accelerating Rotarod}

The locomotor performance was assessed with a five station Rotarod Treadmill for mouse (ENV-575 M, Med associates Inc., St Albans, VT, USA) according to the manufacturer's instructions. Briefly, the mice were put in separated sections on an accelerating rotating rod (4-40 rpm over a 300-speriod) and the latency to fall was recorded. The time spent clinging on the rotating rod without walking was subtracted from the final score. Each mouse was trained for 5 consecutive days before each test.

\section{Grip strength test}

Four-limb grip strength was measured using the Bioseb grip strength tester BIO-G3S (Bioseb, Vitrolles, France). Mice were placed on a grid accessory and pulled firmly backwards by the tail, provoking a grip response. The maximum force exerted on the grid was recorded on the apparatus. The final score was determined by averaging the strength of three trials.

\section{Footprint analysis}

The analysis of the mice hind paw footprints was performed as previously described [85]. Briefly, the hind feet of the mice were coated with non-toxic black ink, so that the mice left a trail of footprints as they walked along a 50-cm-long, $10-\mathrm{cm}$-wide runway. The toe spreading (distance between the first and last toe) and the plantar length (distance between the tip toe and the heel) of three consecutive steps were measured and averaged.

\section{Hot plate test}

The sensitivity to heat was measured using the IITC Life Science Hot plate analgesia meter (IITC Inc. Woodlands Hills, CA, USA) according to the manufacturer instructions. Briefly, each mouse was dropped in a bottom-less glass container placed on a platform heated at $52{ }^{\circ} \mathrm{C}$. The temperature was chosen according to the mouse strain to produce a slight discomfort without inducing pain or injury. The latency before showing a sign of discomfort in the hind paws (licking, fast removal or jump) was recorded. Mice that did not show any sign of discomfort after $20 \mathrm{~s}$ were removed to prevent injury. The final score was determined by averaging the reaction times of three trials.

\section{Nerve conduction studies}

Nerve conduction studies were performed using the NeuroEMG-Micro system (Neurosoft, Ivanovo, Russia). Subdermal 0.4-mm electrodes were used for stimulation and recording on anesthetized mice (5\% isoflurane). Compound muscle action potential amplitudes (CMAPs) were measured by placing the stimulating electrodes at the sciatic notch and the recording electrodes above the gastrocnemius muscle. The CMAPs were measured at supramaximal stimulation. Three consecutive recordings were performed. The highest recorded amplitude and the associated latency were used as final scores.

\section{Tissue harvesting and processing}

After inhalation of a lethal dose of $\mathrm{CO}_{2}$, mice were dissected and the sciatic nerve, spinal cord, and gastrocnemius muscles were harvested, snap frozen in liquid nitrogen, and stored at $-80{ }^{\circ} \mathrm{C}$ for subsequent protein or mRNA analysis. For microscopy analysis, the tibial nerve (distal to the sciatic nerve trifurcation) and gastrocnemius were dissected and fixed in a 3.9\% glutaraldehyde for $48 \mathrm{~h}$ at room temperature. For enzymatic staining, freshly dissected gastrocnemius was snap frozen in cold methyl butane, sliced in $9 \mu \mathrm{m}$ crosssections, and stored at $-80{ }^{\circ} \mathrm{C}$ until further processing. For staining on fixed sections, mice received a lethal dose of xylazine and ketamine mixture before being transcardially perfused with $4 \%$ paraformaldehyde (PFA). The spinal cord, sciatic nerve, and gastrocnemius muscle were harvested, post-fixed in 4\% PFA overnight, and stored in 30\% sucrose phosphate-buffered saline (PBS) solution. 


\section{Histology}

Morphometric study on epoxy semi-thin sections and EM analysis

Nerve and muscle samples were stained with unbuffered aqueous $1 \%$ osmium tetroxide, dehydrated, and embedded in araldite epoxy resin. Semi-thin sections were cut on an ultra-microtome, stained with $1 \%$ toluidine blue, and examined by light microscopy. Images of toluidine blue sections were captured on an Axioskop light microscope (Zeiss, Oberkochen, Germany) equipped with a CCD UC30 camera (Olympus Inc., Tokyo, Japan). Morphometrical evaluation of the axon number in the tibial nerve was performed in sets of images covering the total nerve cross-sectional area using the software ImageJ [70]. The large and medium myelinated axons were manually counted and reported to the nerve area. In addition, samples were analysed using a semi-automatic method to obtain the myelinated fiber size distribution. To this end, images with overlapping regions of the entire nerve were acquired at $40 \times$ magnification (plan achromat objective, pixel size $=0.137 \mu \mathrm{m}$ ) and stitched together using the grid/collection stitching plugin [60] in Fiji software [69]. All stitched images were batch-processed with an ImageJ macro to measure the diameter of all individual axons with an automatic segmentation procedure using the Fiji plugin find connected regions after contrast normalization and unsharp mask, and followed by particle size filtering with the particles analysis tool. Transmission electron microscopy (TEM) of the glutaraldehyde-fixed, resin embedded tissue was performed as previously described [9]. All semithin and EM analyses were done with biological triplicates $(n=3)$.

\section{Staining and immunohistochemistry (IHC)}

The fixed spinal cord lumbar enlargement (containing the neurons innervating the lower limbs) was sliced in $14 \mu \mathrm{m}$ cross sections and stained with cresyl violet to allow neuron quantification. The number of large neurons in the ventral horn of the spinal cord was manually counted using the software image $\mathbf{J}$ [70]. Gastrocnemius sections were processed for hematoxylin/eosin and ATPase stainings or immunostaining using the following antibodies: Hspb8 (ab79784, Abcam, Cambridge, UK), $\alpha$ B-crystallin (ADISPA-222-D, Enzo life science, Farmingdale, NY, USA), and desmin (M076029, Dako, Agilent, Santa Clara, CA, USA). The fixed sciatic nerve was sliced in $7 \mu \mathrm{m}$ longitudinal sections and immunostained for Hspb8 and BAG3 (A302-806A-M, Bethyl Laboratories, Montgomery, TX, USA). Immunohistochemistry was performed as previously described [8]. Briefly, after blocking endogenous peroxidases and unspecific epitopes, sections were incubated overnight at $4{ }^{\circ} \mathrm{C}$ with the primary antibody, $1 \mathrm{~h}$ at room temperature with a horse-radish peroxidase (HRP)-conjugated secondary antibody (Jackson Immuno Research Laboratories Inc., West Grove, PA, USA) and developed using 3,3'-diaminobenzidine (DAB). Sections were counterstained with hematoxylin. Images were taken on an Axioskop light microscope (Zeiss, Oberkochen, Germany) equipped with a CCD UC30 camera (Olympus Inc., Tokyo, Japan). All stainings were done on biological triplicates $(n=3)$.

\section{Western blot analysis}

Samples were homogenized in RIPA buffer (50 mM Tris, $150 \mathrm{mM} \mathrm{NaCl}, 1 \% \mathrm{NP} 40,0.5 \%$ Sodium deoxycholate, and $0.1 \%$ Sodium Dodecyl Sulphate) complemented with protease inhibitors (Complete, Roche Diagnostics, Basel, Switzerland) and phosphatase inhibitors (PhosStop, Roche, Basel, Switzerland). Equal concentrations of proteins, as determined by the BCA protein assay (Thermo Fisher Scientific, Waltham, MA, USA), were mixed with NuPAGE LDS sample buffer, heated to $95{ }^{\circ} \mathrm{C}$ for $10 \mathrm{~min}$, and then separated by NuPAGE Bis-Tris gel (4-12\% polyacrylamide), electro-transferred (XCell SureLock, Invitrogen, Thermo Fisher Scientific, Waltham, MA, USA) onto Nitrocellulose membrane and immunoblotted. Briefly, membranes were blocked in 5\% non-fat dry milk in PBS-Tween $(0.1 \%)$ for $1 \mathrm{~h}$ at room temperature and incubated overnight at $4{ }^{\circ} \mathrm{C}$ with a primary antibody. The membranes were incubated with HRP-linked secondary antibody treated with Enhanced Chemiluminescence ECL Plus kit reagents (Thermo Fisher Scientific, Waltham, MA, USA) and imaged with ImageQuant imager (GE Healthcare, Wauwatosa, WI, USA). The following antibodies were used: Hsp22 (3059, Cell Signaling, Danvers, MA, USA), N-terminal Hsp22 (SAB2101100, Sigma-Aldrich, St Louis, MO, USA), BAG3 (A302806A-M, Bethyl Laboratories, Montgomery, TX, USA), LC3B (L7543, Sigma-Aldrich, St Louis, MO, USA), p62 (sc-25575, Santa Cruz Biotechnology Inc., Dallas, TX, USA), GAPDH (GTX627408, Gene Tex Inc., Irvine, CA, USA), and the following HRP-conjugated secondary antibodies: anti-mouse IgG1 (1070-05, Southern Biotec, Birmingham, AL, USA), anti-mouse IgG2b (1090-05, Southern Biotec, Birmingham, AL, USA), and anti-rabbit (W401B, Promega, Madison, WI, USA). Western blots were quantified using ImageJ [70] software as previously described [39]. Briefly, band intensity was determined by the 'mean pixel gray' values after Gaussian blur and background subtraction. The 'mean pixel gray' value of each protein of interest was then normalized to the 'mean pixel gray' value of the loading control and presented as relative quantities. All western blot analyses were run with biological triplicates $(n=3)$. 


\section{Quantitative RT-PCR}

The frozen tissue was homogenized in Trizol and total RNA was extracted using the RNeasy lipid tissue kit (Qiagen, Venlo, The Netherlands) according to the manufacturer's protocol. Possible residual DNA contamination was eliminated by DNase treatment (Ambion, Thermo Fisher Scientific Inc., Waltham, MA, USA). RNA was then converted into cDNA using the SuperScript ${ }^{\circledR}$ III reverse transcriptase (life technologies, Carlsbad, CA, USA). Real-time quantitative polymerase chain (RT-qPCR) reactions were done with 10 ng cDNA diluted in SYBR Green mix (Life Technologies, Carlsbad, CA, USA) and run on a ViiA 7 Real-Time PCR System (Applied Biosystems, Thermo Fisher Scientific Inc., Waltham, MA, USA) with gene-specific primers (mHspb8 5'-AGACCCCTTTCGGGACTCA-3'/5'-GGCTGT CAAGTCGTCTGGAA-3'). Primers were designed making use of Primerbank (http://www.pga.mgh.harvard.edu/primerbank). One sample from each target was used as no-RT control to attest the absence of genomic DNA contamination. Relative gene expression was calculated using the $\Delta \Delta \mathrm{C}_{\mathrm{T}}$ method [37] and normalized with geometric mean of at least three housekeeping genes. All quantitative RT-PCR analyses were run with biological triplicate.

\section{Statistical analysis}

Statistical analyses were performed using GraphPad Prism version 6 (GraphPad, La Jolla, CA, USA). Differences between genotypes over different ages were tested using two-way repeated-measures ANOVA and Tukey's post hoc analysis. Comparisons of two data sets were analysed by Student's $t$ test. Values are expressed as mean \pm SD. Statistical significance was set at $p<0.05$. All analyses were performed blind to the genotype of the mice.

\section{Results}

\section{Generation of the Hspb8 KI and KO lines}

The transgenic Hspb8 KI and $\mathrm{KO}$ mouse lines were generated using a single targeting vector encompassing K141N (c.423G > C) point mutation, responsible for dHMN [43], integrated in exon 2 of the endogenous mouse $H s p b 8$ gene. We developed a gene targeting construct containing the mutated exon 2, a neomycin resistance (Neo) gene cassette downstream of exon 2 flanked by two $F R T$ sites and two loxP sites (one situated upstream of exon 2 and the other downstream of $\mathrm{Neo}$ ) (Fig. 1a). Male chimeras were used for germline transmission and F1-generation mice were backcrossed to the C57BL/6J line to generate a stable colony carrying the $\mathrm{Hspb} 8^{\mathrm{K} 141 \mathrm{~N}}$ allele. $\mathrm{Hspb} 8^{\mathrm{K} 141 \mathrm{~N} /+}$ mice were bred to generate $\mathrm{Hspb} 8^{\mathrm{K} 141 \mathrm{~N} / \mathrm{K} 141 \mathrm{~N}}, \mathrm{Hspb} 8^{\mathrm{K} 141 \mathrm{~N} /+}$, and WT littermates $\left(\mathrm{Hspb}^{+/+}\right)$. The functional $\mathrm{KO}$ mouse lines were activated by excision of exon 2 following Cre-lox recombination by crossing $\mathrm{Hspb} 8^{\mathrm{K} 141 \mathrm{~N}}$ mice with Sox 2 -Cre mice [51] (Fig. 1a). The mice genotype was identified by PCR using specific primers to detect Cre recombinase and to differentiate the WT allele (188 bp) from the KI (235 bp) allele (Fig. 1b), and to differentiate the WT or KI alleles (1335/1377 bp) from the KO allele (390 bp) (Fig. 1c). The presence of the $\mathrm{K} 141 \mathrm{~N}$ point mutation was further validated by Sanger sequencing (Fig. 1d). The homozygous KI mice had normal Hspb8 mRNA and protein levels in the spinal cord, where the protein is highly expressed (Fig. 1f-h), suggesting that the point mutation is not affecting the transcription or the protein stability in this tissue. In the functional $\mathrm{KO}$ mice, the excision of Hspb8 exon 2 did not significantly affect its mRNA expression (Fig. 1i). However, the protein could not be detected by western blot using an antibody targeting an epitope coded by the exon 1 of the $H s p b 8$ mouse gene (Fig. 1e). The generated transgenic mouse lines had a normal lifespan and weight. Their feeding, grooming, and mating behaviours were comparable to those of $\mathrm{C} 57 \mathrm{bl} / 6$ wild-type mice.

\section{$\mathrm{Hspb8}^{\mathrm{K} 141 \mathrm{~N} / \mathrm{K} 141 \mathrm{~N}}$ mice develop a progressive defect in motor functions}

The Hspb8 $8^{\mathrm{K} 141 \mathrm{~N} / \mathrm{K} 141 \mathrm{~N}}, \mathrm{Hspb} 8^{\mathrm{K} 141 \mathrm{~N} /+}, \mathrm{Hspb} 8^{-/-}$, and $\mathrm{Hspb} 8^{-/+}$mice and their WT littermates were screened for motor or sensory deficits at 3, 6, 9, and 12 months of age. The KI lines $\left(\mathrm{Hspb} 8^{\mathrm{K} 141 \mathrm{~N} / \mathrm{K} 141 \mathrm{~N}}, \mathrm{Hspb} 8^{\mathrm{K} 141 \mathrm{~N} /+}\right)$ were also tested at 18 month. None of the mice showed clasping behaviour and no difference in footprint could be detected between the transgenic heterozygous and homozygous KI and KO mice and their respective WT littermates. From the age of 9 months, the homozygous mutant $\mathrm{Hspb} 8^{\mathrm{K} 141 \mathrm{~N} / \mathrm{K} 141 \mathrm{~N}}$ mice showed a progressive and significant decline in the locomotor performance assessed by the Rotarod (Fig. 2a). A decline was also observed at the grip strength test where the $\mathrm{Hspb} 8^{\mathrm{K} 141 \mathrm{~N} / \mathrm{K} 141 \mathrm{~N}}$ mice achieved a significantly lower performance than their WT littermates at 18 month (Fig. 2c). However, the $\mathrm{Hspb} 8^{\mathrm{K} 141 \mathrm{~N} / \mathrm{K} 141 \mathrm{~N}}$ mice score at the hot plate test was normal (Fig. 2e), suggesting that the sensory functions were preserved. The motor deficit was further supported by a drastic and significant reduction of the amplitude of the compound motor action potentials (CMAPs) in the $\mathrm{Hspb} 8^{\mathrm{K} 141 \mathrm{~N} / \mathrm{K} 141 \mathrm{~N}}$ mice from the age of 6 months onwards (Fig. 2g), while the nerve conduction velocities were normal, hinting for axonal loss rather than demyelination of the nerve. On the other hand, the heterozygous $\mathrm{Hspb} 8^{\mathrm{K} 141 \mathrm{~N} /+}$ mice performances did not differ from the WT (Supplementary Fig. S1). These mice were, therefore, not included in further analyses. These data demonstrate that homozygous 
a
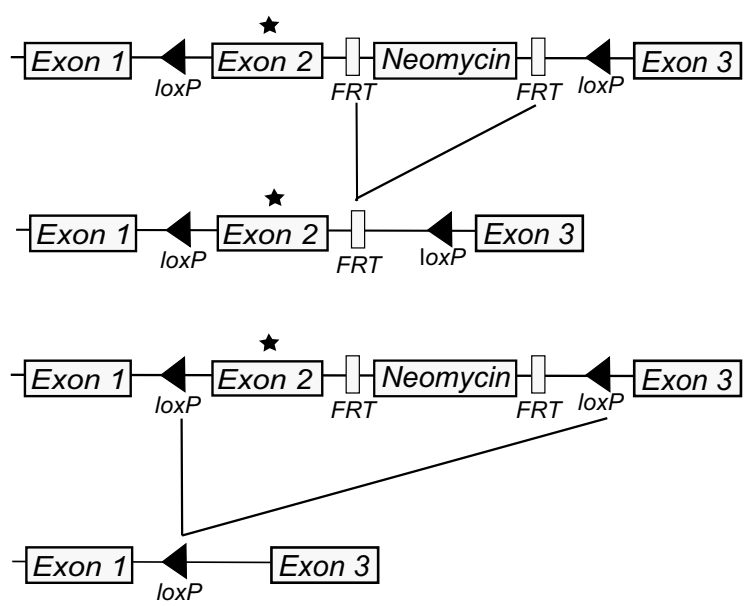

b

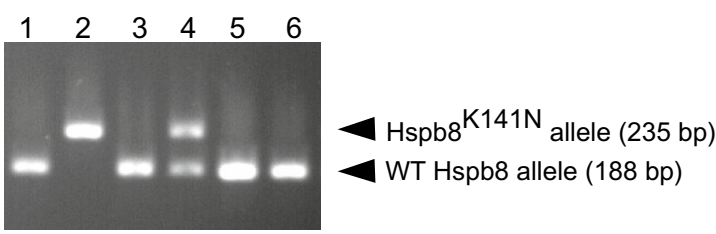

C

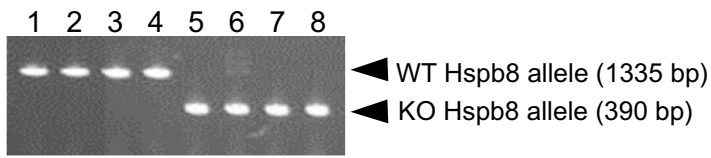

d

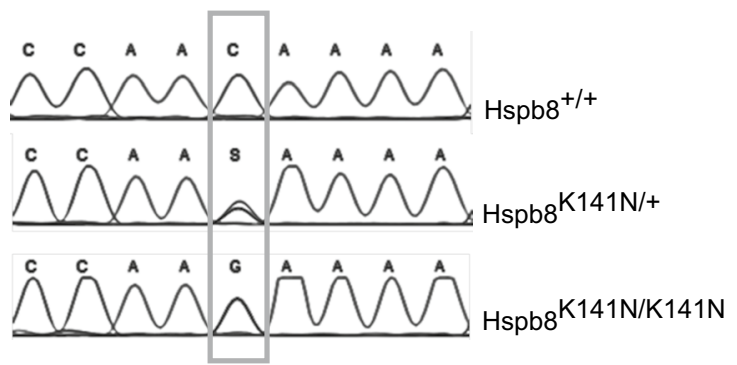

Fig. 1 Generation and validation of the $\mathrm{Hspb} 8^{\mathrm{K} 141 \mathrm{~N}} \mathrm{KI}$ and $\mathrm{Hspb} 8$ KO lines. a Schematic representation of the mouse Hspb8 allele showing the Neomycin gene (Neo) flanked by two FRT sites upstream of exon 2. The exon 2 and the Neo gene are floxed by two loxP sites. Expression of the FLP recombinase allows excision of the Neo gene cassette, while expression of Cre recombinase allows CreloxP recombination and excision of the exon 2 of the $H s p b 8$ gene as well as the Neo cassette. b Photograph showing the products of the Exon 2_loxP genotyping by PCR. The $188 \mathrm{bp}$ and $235 \mathrm{bp}$ amplicons resulted from the amplification of the wild-type (WT) and mutant Hspb8 alleles, respectively. Lanes 1, 3, 5, and 6 represent genotypes of WT littermates, lane 2 of a homozygous KI animal, and lane 4 of a heterozygous KI animal. c Photograph showing the products of the KO genotyping by PCR. The 1335 and 390 bp amplicons resulted from the amplification of the wild-type $H s p b 8$ allele and the allele lacking exon 2 , respectively. The lanes $1-4$ represent genotypes of e
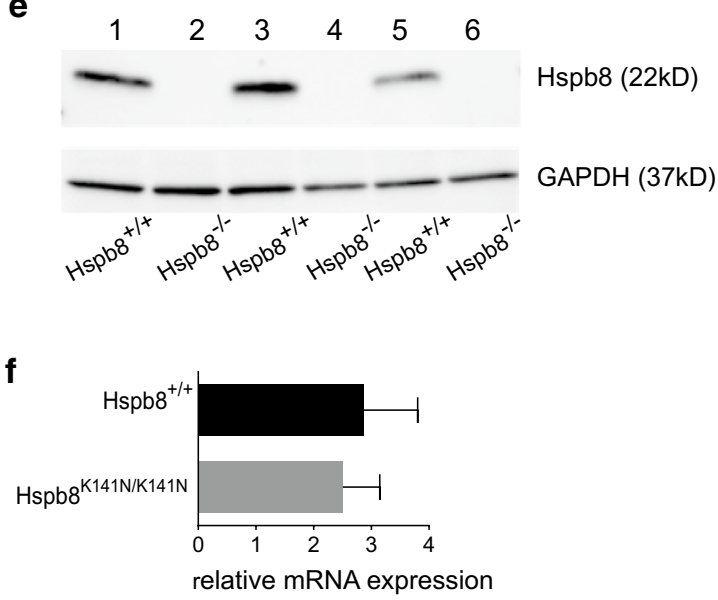

g

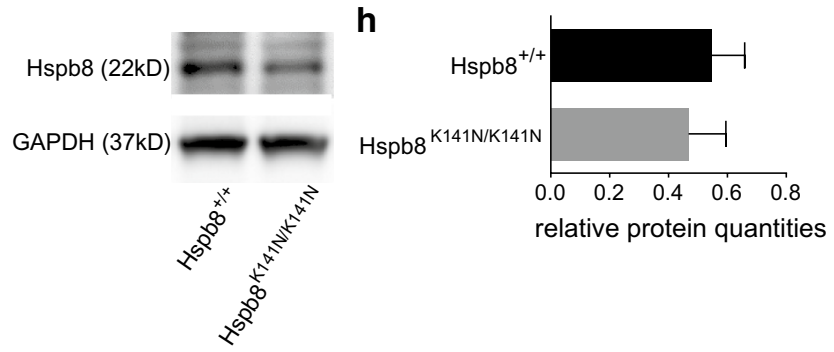

i

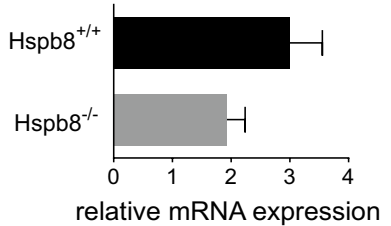

WT animals; lanes 5-8 of homozygous KO animals. d Sequencing of the exon 2 of the mouse $H s p b 8$ gene showing the presence of the point mutation in a single allele of an heterozygous and homozygous animal. e Representative western blot analysis of mouse Hspb8 protein level in the sciatic nerve of 2-month-old $\mathrm{KO} \mathrm{Hspb8}{ }^{-1-}$ mice (lanes 2, 4, and 6 ) and WT littermates (lanes 1, 3 and 5) showing that only the protein lysate from WT produces a band. GAPDH is used as a loading control. f Relative quantities $\left(\Delta \Delta \mathrm{C}_{\mathrm{T}}\right)$ of $\mathrm{Hspb} 8 \mathrm{mRNA}$ in the spinal cord of 2-month-old $\mathrm{Hspb} 8^{\mathrm{K} 141 \mathrm{~N} / \mathrm{K} 141 \mathrm{~N}}$ and $\mathrm{Hspb} 8^{+/+}$mice. Values are expressed as mean $\pm \mathrm{SD}, N=3$. g Representative western blot analysis of Hspb8 in the spinal cord of 2-month-old Hspb8 $8^{\mathrm{K} 141 \mathrm{~N} /}$ $\mathrm{K} 141 \mathrm{~N}$ and $\mathrm{Hspb}^{+/+}$mice and quantification of Hspb8 bands normalized on GAPDH (h). Values are expressed as mean $\pm \mathrm{SD}, N=3$. i Relative quantities $\left(\Delta \Delta \mathrm{C}_{\mathrm{T}}\right)$ of Hspb8 mRNA in the spinal cord of 2-month-old $\mathrm{Hspb} 8^{-/-}$and $\mathrm{Hspb} 8^{+/+}$mice. Values are expressed as mean $\pm \mathrm{SD}, N=3$ 
Fig. 2 Assessment of motor and sensory functions in the $\mathrm{Hspb}^{\mathrm{K} 141 \mathrm{~N}} \mathrm{KI}$ and $\mathrm{Hspb} 8 \mathrm{KO}$ lines. a, b Rotarod performance showing the average time, in seconds (s), spent on the accelerating rotating rod at 3 , $6,9,12$, and 18 months of age in $\mathrm{Hspb} 8^{\mathrm{K} 141 \mathrm{~N} / \mathrm{K} 141 \mathrm{~N}}$ mice and their WT littermates (a) and at $3,6,9$, and 12 months of age in $\mathrm{Hspb}^{-/-}$mice and their WT littermates (b). c, d Average score on the grip strength over time in $\mathrm{Hspb} 8^{\mathrm{K} 141 \mathrm{~N} / \mathrm{K} 141 \mathrm{~N}}$ mice and their WT littermates (c) and in $\mathrm{Hspb} 8^{-/-}$mice and their WT littermates (d). e, f Hind paws sensitivity to heat shown by the average reaction time, in milliseconds (ms), before showing a sign of discomfort in $\mathrm{Hspb} 8^{\mathrm{K} 141 \mathrm{~N} / \mathrm{K} 141 \mathrm{~N}}$ mice and their WT littermates (e) and in $\mathrm{Hspb} 8^{-/-}$mice and their WT littermates (f). $\mathbf{g}, \mathbf{h}$ Average CMAPs amplitude in $\mathrm{Hspb} 8^{\mathrm{K} 141 \mathrm{~N} / \mathrm{K} 141 \mathrm{~N}}$ mice and their WT littermates $(\mathbf{g})$ and in $\mathrm{Hspb}^{-/-}$mice and their WT littermates (h). Values are expressed as mean $\pm \mathrm{SD}, N=9$. ${ }^{*} p<0.05$, and $* * p<0.01$
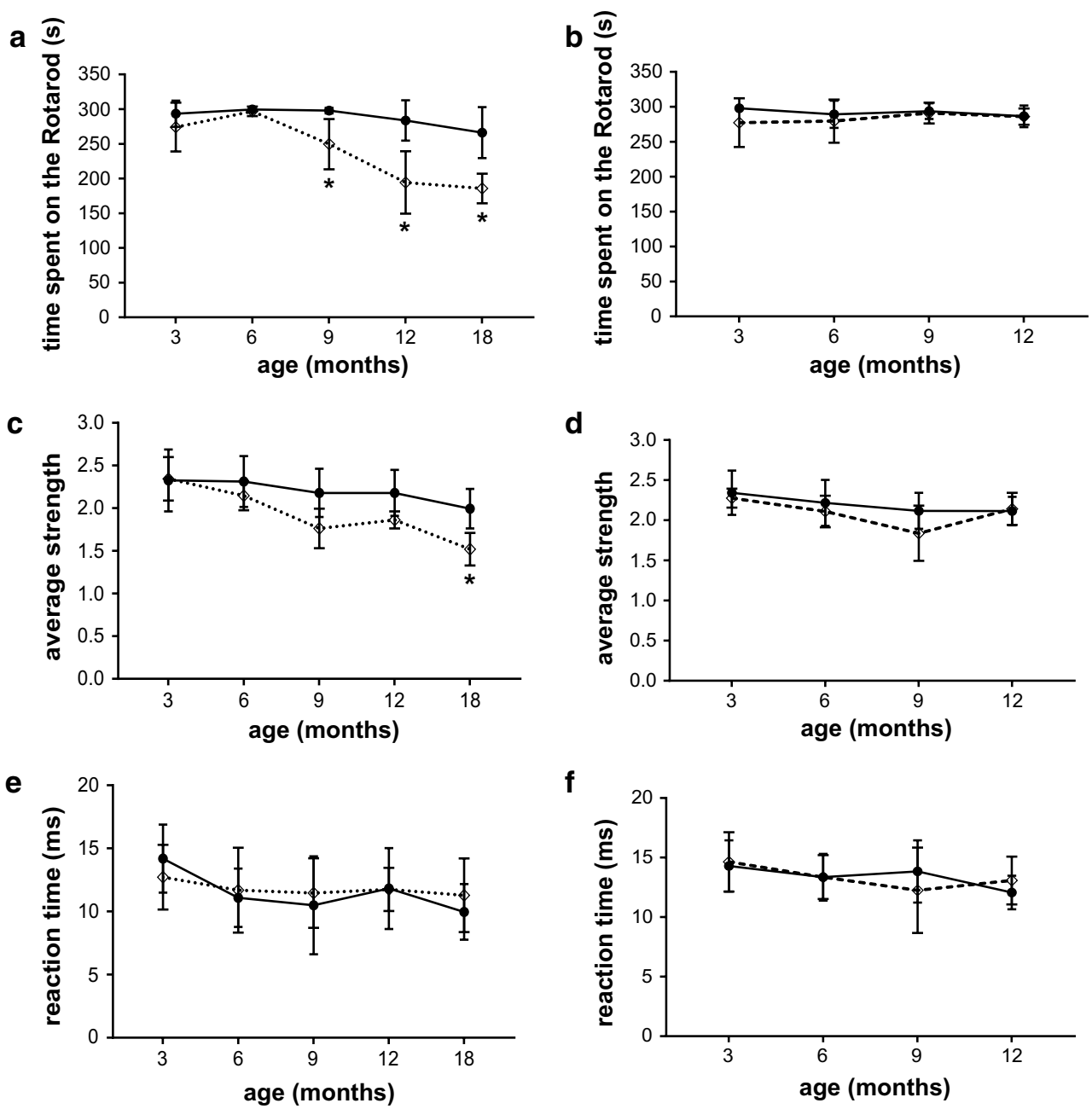

\section{f}
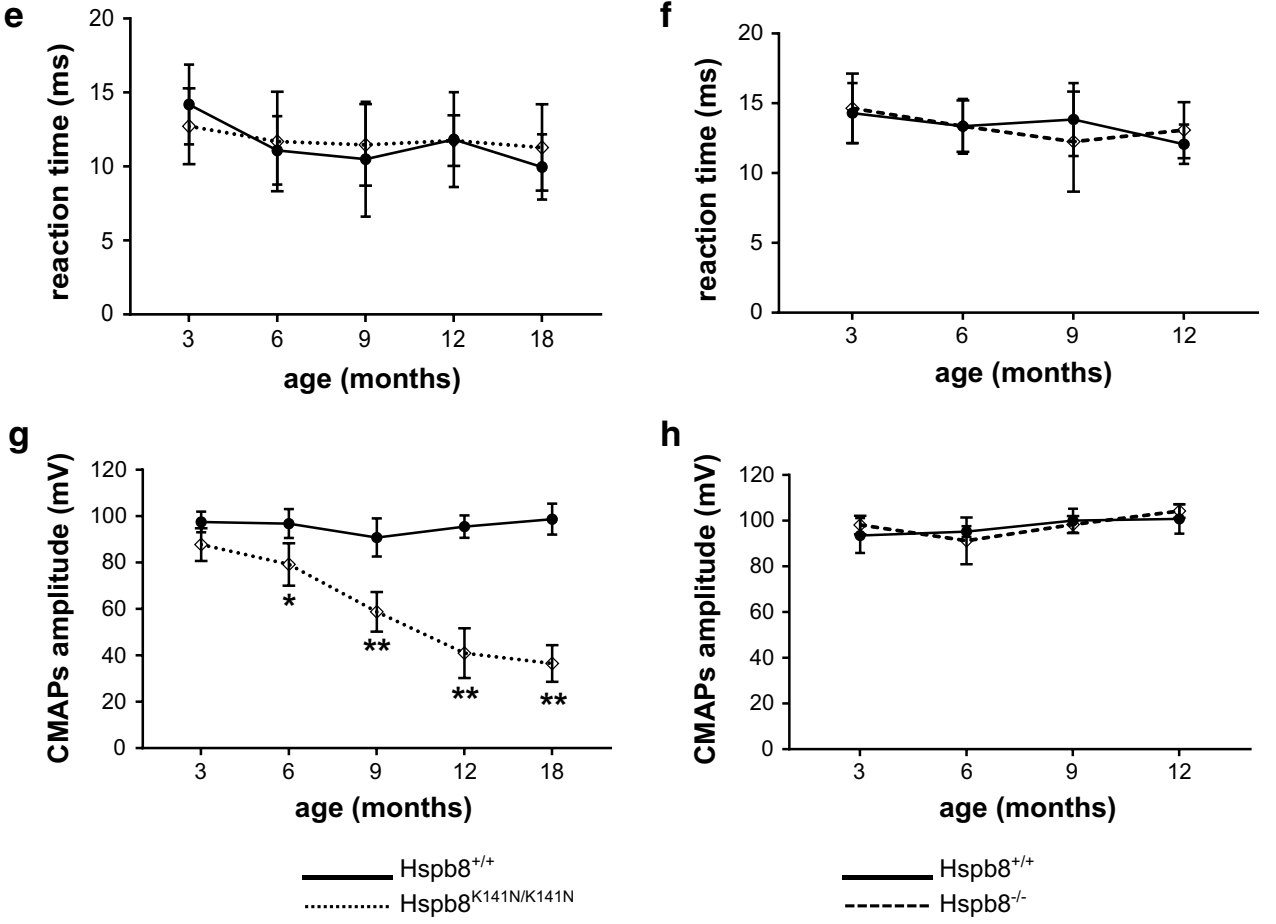

expression of $\mathrm{Hspb} 8^{\mathrm{K} 141 \mathrm{~N}}$ mutation induces motor behavioural and electrophysiological impairments without sensory abnormalities similar to the dHMN type II phenotype [75]. Interestingly, neither the homozygous $\mathrm{Hspb}^{-/-}$mice (Fig. 2) nor the heterozygous $\mathrm{Hspb}^{-/+}$(Supplementary Fig. S1) developed motor or sensory deficits or CMAPs abnormalities suggesting that part of the motor phenotype observed in the $\mathrm{Hspb} 8^{\mathrm{K} 141 \mathrm{~N} / \mathrm{K} 141 \mathrm{~N}}$ mice is the consequence of a toxic gain-of-function of the mutant protein.

\section{$\mathrm{Hspb8}^{\mathrm{K} 141 \mathrm{~N} / \mathrm{K} 141 \mathrm{~N}}$ mice show severe axonal degeneration}

To determine if the reduced CMAPs amplitude was associated with axonal degeneration, we quantified the number of myelinated axons on Toluidine blue-stained semi-thin cross sections of the distal sciatic nerve (tibial nerve) of 18-monthold Hspb8 ${ }^{\mathrm{K} 141 \mathrm{~N} / \mathrm{K} 141 \mathrm{~N}}$ mice (Fig. 3b) and their WT littermates (Fig. 3a). The densities of large and medium myelinated axons were significantly lower in the Hspb8 ${ }^{\mathrm{K} 141 \mathrm{~N} / \mathrm{K} 141 \mathrm{~N}}$ mice 
compared to their WT littermates (Fig. 3c, d), similar as seen in the severe peripheral axon loss reported in the postmortem neuropathological analysis of a dHMN patient [58]. Quantification of the large neurons in the ventral horn of the spinal cord showed that despite the severe distal axon loss, the motoneuron cell bodies were spared (Supplementary Fig. $\mathrm{S} 2 \mathrm{a}, \mathrm{b})$. Importantly, the reduction in axon density seen in 18-month-old $\mathrm{Hspb} 8^{\mathrm{K} 141 \mathrm{~N} / \mathrm{K} 141 \mathrm{~N}}$ mice could not be detected in 2-month-old mice (Supplementary Fig. S2c-e). This led us to attribute the axon loss in the $\mathrm{Hspb} 8^{\mathrm{K} 141 \mathrm{~N} / \mathrm{K} 141 \mathrm{~N}}$ mice to progressive axonal degeneration rather than a developmental defect. In 12-month-old $\mathrm{Hspb} 8^{\mathrm{K} 141 \mathrm{~N} /+}$ mice (Supplementary Fig. S3a-c) and Hspb $8^{-/-}$mice (Supplementary Fig. S2f-h), similar analyses failed to demonstrate axon loss, supporting the absence of neuropathy in these mice. At the ultrastructural level, distal sciatic nerves of 18-month-old $\mathrm{Hspb} 8^{\mathrm{K} 141 \mathrm{~N} /}$
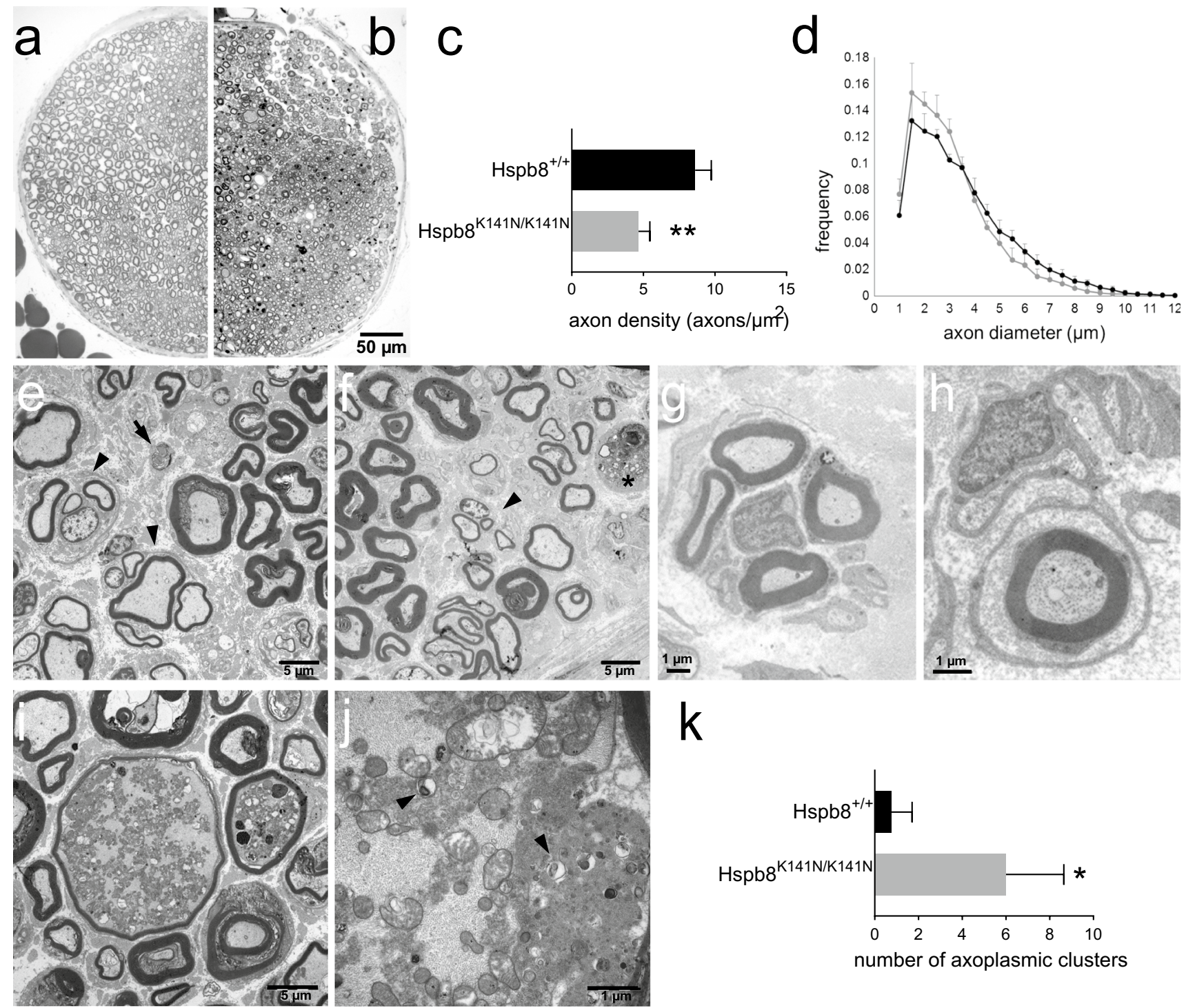

$\mathrm{k}$

Fig. 3 Characterization of distal sciatic nerve pathology associated with $\mathrm{Hspb} 8^{\mathrm{K} 141 \mathrm{~N}}$ mutation. a, b Toluidine-blue stained semi-thin sections of the tibial nerve of 18-month-old WT $\mathrm{Hspb}^{+/+}$(a) and $\mathrm{Hspb}^{\mathrm{K} 141 \mathrm{~N} / \mathrm{K} 141 \mathrm{~N}}$ (b) mice. c Density of large and medium myelinated axons in the tibial nerve of 18-month-old $\mathrm{Hspb} 8^{\mathrm{K} 141 \mathrm{~N} / \mathrm{K} 141 \mathrm{~N}}$ and $\mathrm{Hspb}^{+/+}$mice. Values are expressed as mean $\pm \mathrm{SD}, N=3$. $* * p<0.01$. d Axon diameter distribution. Values are expressed as mean $\pm \mathrm{SD}, N=3$. e, f Electron microscopy images of the tibial nerve of 18 -month-old $\mathrm{Hspb} 8^{\mathrm{K} 141 \mathrm{~N} / \mathrm{K} 141 \mathrm{~N}}$ mice showing axonal degeneration (arrow), regenerative clusters (arrow head), and macrophages (asterisk). g, h Electron microscopy images of the sural nerve of the CMT-M:V.6 patient showing a regenerative cluster (g) and an onionbulb like pattern (h). i Electron microscopy images of the tibial nerve of $\mathrm{Hspb} 8^{\mathrm{K} 141 \mathrm{~N} / \mathrm{K} 141 \mathrm{~N}}$ mice showing axoplasmic accumulation of osmiophilic material. $\mathbf{j}$ Higher magnification micrograph of the accumulated axoplasmic material showing mitochondria undergoing mitophagy (arrow heads). $\mathbf{k}$ Total number of axoplasmic clusters per nerve cross section in $\mathrm{Hspb} 8^{\mathrm{K} 141 \mathrm{~N} / \mathrm{K} 141 \mathrm{~N}}$ mice and controls. Values are expressed as mean $\pm \mathrm{SD}, N=3 . * p<0.05$ 


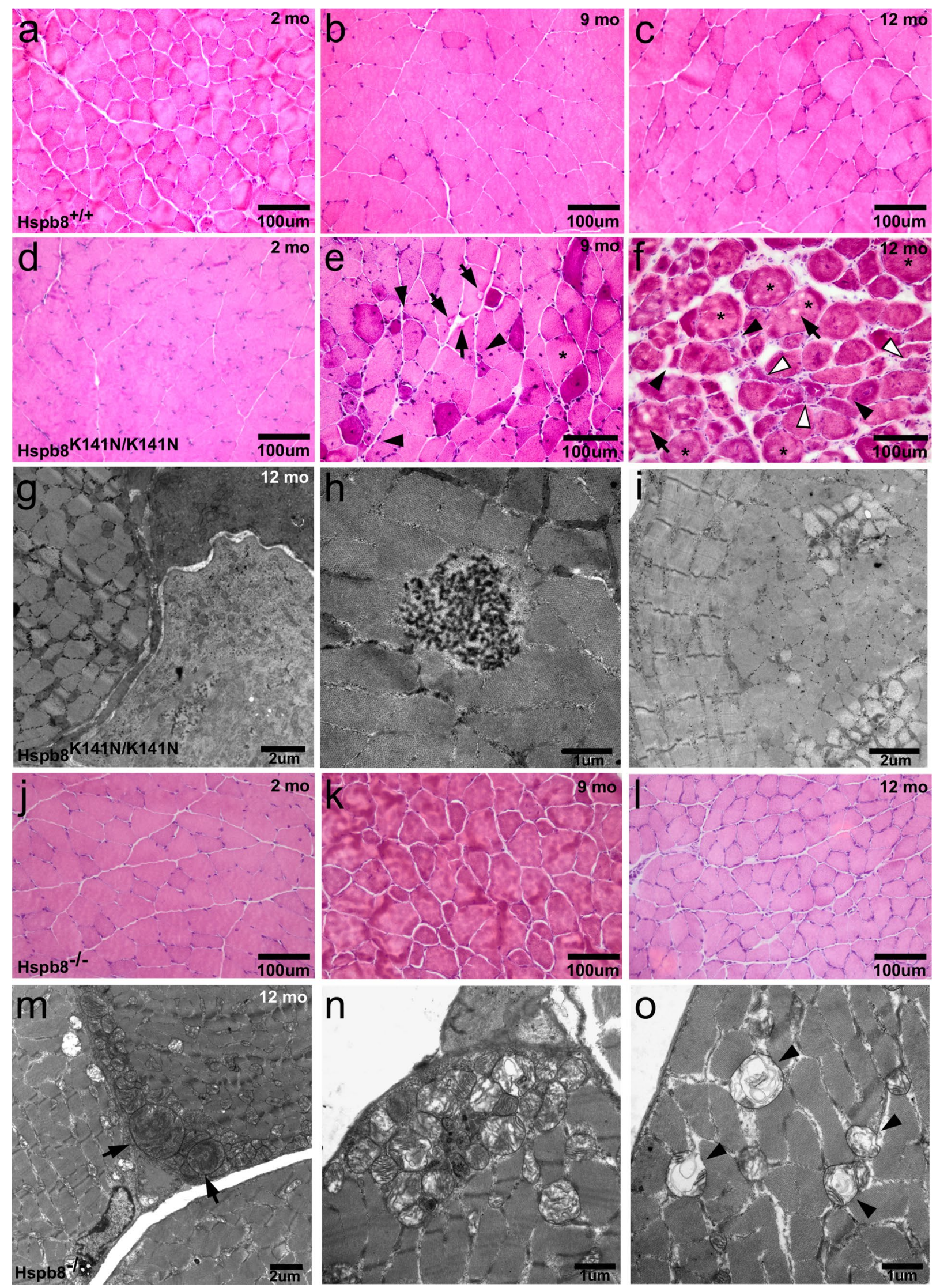


4Fig. 4 Gastrocnemius muscle histopathology in the $\mathrm{Hspb} 8^{\mathrm{K} 141 \mathrm{~N}} \mathrm{KI}$ and Hspb8 KO lines. a, c Haematoxylin and eosin (H\&E)-stained cross sections of the gastrocnemius muscle of 2-month-old (a), 9-month-old (b) and 12-month-old (c) $\mathrm{Hspb}^{+/+}$mice. d, f H\&Estained cross sections of the gastrocnemius muscle of 2 month old (d), 9-month-old (e), and 12-month-old (f) $\mathrm{Hspb} 8^{\mathrm{K} 141 \mathrm{~N} / \mathrm{K} 141 \mathrm{~N}}$ mice. e, f Rimmed vacuoles (black arrows), necrotic (white arrowheads), atrophied (black arrowheads), and hypertrophic fibers (asterisks) in 9-month-old (e) and 12-month-old (f) $\mathrm{Hspb}^{\mathrm{K} 141 \mathrm{~N} / \mathrm{K} 141 \mathrm{~N}}$ mice. g, i Electron microscopy images of the gastrocnemius muscle of a 12-month-old $\mathrm{Hspb} 8^{\mathrm{K} 141 \mathrm{~N} / \mathrm{K} 141 \mathrm{~N}}$ mouse showing myofibers at different stages of atrophy (g); accumulation of granulofilamentous material (h) and a ring fiber showing classical features with peripheral longitudinal myofibrils and centrally transverse myofibrils (i). j, l H\&Estained cross sections of the gastrocnemius muscle of 2-month-old (j), 9-month-old (k) and 12-month-old (l) $\mathrm{Hspb}^{-/-}$mice. m-o Electron microscopy images of the gastrocnemius muscle of a 12-monthold $\mathrm{Hspb}^{---}$mouse showing intact myofibrils and normal Z-disc organisation (m), enlarged mitochondria with altered cristae (arrow) $(\mathbf{m})$, accumulation of altered mitochondria, some possibly undergoing mitophagy (n), and mitochondria presenting degenerating cristae and abnormal matrix (arrow heads) (o)

K141N mice demonstrated histopathological changes such as axonal atrophy, regenerative clusters, and infiltration by macrophages (Fig. 3e-f). In addition, Hspb $8^{\mathrm{K} 141 \mathrm{~N} / \mathrm{K} 141 \mathrm{~N}}$ mice sciatic axons displayed focal accumulations of mitochondria, some of them undergoing mitophagy, as well as other degenerating organelles (Fig. 3i, j). This accumulation of axoplasmic material has already been described in a case of CMT2E neuropathy caused by NEFL gene mutations [26, 84] and is thought to result from axoplasmic flow disturbance. These clusters of axoplasmic degenerative material were significantly more frequent in $\mathrm{Hspb} 8^{\mathrm{K} 141 \mathrm{~N} / \mathrm{K} 141 \mathrm{~N}}$ than in WT mice (Fig. 3k). Interestingly, the distal sciatic nerve of heterozygous Hspb8 ${ }^{\mathrm{K} 141 \mathrm{~N} /+}$ mice also displayed, although to a lesser extent, regenerative clusters, macrophage infiltration, and accumulation of axoplasmic material (Supplementary Fig. S3d, e), as well as myelinated Remak bundles which suggest abnormal cycles of regeneration and remyelination (Supplementary Fig. S3f). It is so far difficult to determine if the sciatic nerve of HSPB8-linked dHMN II patients shows a similar pattern because of the absence of motor nerve biopsies. However, a biopsy of the sensory branch of the superficial peroneal nerve of one patient belonging to the large Belgian family with the HSPB8_K141N mutation (patient CMT-M:V.6) was analysed and no major abnormalities were found in the ultrastructure apart from a regenerative cluster (Fig. 3g), three small Schwann cell onion bulb-like formations (Fig. 3h), and a minimal reduction in unmyelinated axons [77].

\section{Hspb8 $^{\mathrm{K} 141 \mathrm{~N} / \mathrm{K} 141 \mathrm{~N}}$ mice develop muscle atrophy with myofibrillar alterations}

The peroneal brevis muscle biopsy of the same CMTM:V.6 patient showed a total fatty degeneration with only few residual atrophic muscle fibers [77]. This led us to proceed with the histopathology of a hind limb distal muscle innervated by the sciatic nerve, the gastrocnemius muscle. Haematoxylin and eosin (HE) staining of transversal sections of the gastrocnemius muscle showed that the myofibers of 2-month-old Hspb8 ${ }^{\mathrm{K} 141 \mathrm{~N} / \mathrm{K} 141 \mathrm{~N}}$ (Fig. 4d) and WT mice (Fig. 4a) were of regular size and displayed a normal morphology with most nuclei positioned at the normal subsarcolemmal location. In contrast, the 9-month-old Hspb8 ${ }^{\mathrm{K} 141 \mathrm{~N} /}$ K141N mice (Fig. 4e), but not their WT littermates (Fig. 4b), displayed an increased number of myofibers with non-subsarcolemmal nuclei, a marked discrepancy in myofiber size, some of them being atrophic, and several rimmed vacuoles. In the 12-month-old $\mathrm{Hspb} 8^{\mathrm{K} 141 \mathrm{~N} / \mathrm{K} 141 \mathrm{~N}}$ mice gastrocnemius muscle, internalized nuclei were more frequent, size variability was markedly increased, and angulated (but nongrouped), and rounded atrophic fibers could be seen as well as hypertrophic fibers, clumped nuclei, rimmed vacuoles, and endomysial fibrosis (Fig. 4f). Notably, the myofibers of 12-month-old WT mice also showed some size variability (Fig. 4c), but much less pronounced than in Hspb8 $8^{\mathrm{K} 141 \mathrm{~N} /}$ $\mathrm{K} 141 \mathrm{~N}$ mice, reflecting the normal aging process of skeletal muscle in these mice. Interestingly, the fiber-type pattern of the $\mathrm{Hspb} 8^{\mathrm{K} 141 \mathrm{~N} / \mathrm{K} 141 \mathrm{~N}}$ mice was not grouped and was similar to WT littermates (Supplementary Fig. S4e-f), suggesting that the muscle atrophy had a myogenic rather than neurogenic origin. The myopathic phenotype in $\mathrm{Hspb} 8^{\mathrm{K} 141 \mathrm{~N} /}$ K141N mice was further validated and refined by EM analyses showing severe myofiber degeneration (Fig. 4g), accumulations of electron dense granulofilamentous material (Fig. 4h), and ring fibers (Fig. 4i); these features are often associated with myofibrillar myopathy (MFM) [17]. These data echo the recent description of a MFM-like phenotype in two families with the HSPB8 (c.421A > G;p.K141E) mutation [34]. The H\&E-stained muscle sections of 12-month-old heterozygous $\mathrm{Hspb} 8^{\mathrm{K} 141 \mathrm{~N} /+}$ mice were comparable to WT (Supplementary Fig. S3 g, h), while EM analysis revealed signs of Z-band disintegration (Supplementary Fig. S3i), accumulation of electron-dense material (Supplementary Fig. S3j), and a small, empty vacuole (Supplementary Fig. S3 k). Similar histopathological studies were carried out in the KO lines and showed a subtle increase in myofiber size variability in $\mathrm{Hspb} 8^{-/-}$mice (Fig. $4 \mathrm{j}-\mathrm{l}$ ) with age comparable to what was seen in WT animals. Further EM analyses in the gastrocnemius of $\mathrm{Hspb} 8^{-/-}$mice showed the absence of atrophic or necrotic fibers, preserved Z-disc structure (Fig. 4m), and accumulation of pathologic mitochondria many of which presented with degenerating cristae and abnormal matrix (Fig. 4n, o). These data suggest that loss of function of Hspb8 may affect mitochondrial homeostasis, but does not lead to myofibrillar myopathy, while mutant Hspb8 causes progressive and severe myopathy with a distinct myofibrillar component. 


\section{Mutant Hspb8 causes aggregation of myofibril components and autophagy defects in the muscle}

Because aggregation of myofibrillar or ectopic proteins is a major hallmark of MFM [47], we looked for desmin and $\alpha \mathrm{B}$-crystallin, also known as HSPB5 or CRYAB, in the muscle of 12-month-old $\mathrm{Hspb} 8^{\mathrm{K} 141 \mathrm{~N} / \mathrm{K} 141 \mathrm{~N}}$ mice and their WT littermates. While $\alpha \mathrm{B}$-crystallin immunoreactivity was found sub-sarcolemmaly and colocalizing with the Z-disc in the WT animals (Fig. 5a), large aggregates were observed in many muscle fibers of the Hspb8 ${ }^{\mathrm{K} 141 \mathrm{~N} /}$ K141N mice (Fig. 5b). Similar patterns were observed for desmin (Fig. 5d, e). No $\alpha \mathrm{B}$-crystallin and desmin aggregates were found in the 12 -month-old $\mathrm{Hspb}^{-/-}$mice (Fig. 5c, f) which corroborates with the absence of an MFM phenotype in these mice. As expected, Hspb8 forms also aggregates in $\mathrm{Hspb} 8^{\mathrm{K} 141 \mathrm{~N} / \mathrm{K} 141 \mathrm{~N}}$ mice (Fig. 5h), while it follows a certain sarcomeric structure in WT (Fig. 5g). Comparable aggregates could not be found in Hspb8 $8^{\mathrm{K} 141 \mathrm{~N} /+}$ mice (Supplementary Fig. S31). As expected, no Hspb8 immunoreactivity could be seen in KO tissue (Fig. 5i). Taken together, these findings are in concordance with the HSPB8, desmin, and $\alpha \mathrm{B}$-crystallin aggregates found in the patients with a different mutation in the same lysine residue, the K141E missense mutation [34]. To expand our understanding of the disease mechanism, we proceeded with protein expression analyses of Hspb8 and its main interactor Bag3 in 2-month-old (presymptomatic) and 12-month-old (symptomatic) mice. In addition, we also quantified the protein levels of p62, a substrate for autophagy, and of the autophagosomeassociated lipidated form of LC3B (LC3BII), both used as common markers for autophagy. Compared to WT littermates, the muscle of symptomatic Hspb8 $8^{\mathrm{K} 141 \mathrm{~N} / \mathrm{K} 141 \mathrm{~N}}$ mice displayed a significant increase in HSPB8, p62, and LC3BII, while Bag3 levels were decreased (Fig. 5j, k). For p62, an increase could also be observed in 2-monthold Hspb8 $8^{\mathrm{K} 141 \mathrm{~N} / \mathrm{K} 141 \mathrm{~N}}$ mice. The increase in Hspb8 level observed in 12-month-old $\mathrm{Hspb} 8^{\mathrm{K} 141 \mathrm{~N} / \mathrm{K} 141 \mathrm{~N}}$ mice correlates with the accumulation of Hspb8 aggregates previously described. The downregulation of the Bag3 protein level in the same mice could suggest a deficit in Bag3mediated autophagy. In addition, the significant increase in p62, a substrate of autophagy, in 2-month-old and 12-month-old Hspb8 $8^{\mathrm{K} 141 \mathrm{~N} / \mathrm{K} 141 \mathrm{~N}}$ mice (Fig. 5j, k) could reflect a failure in autophagy. The increase in LC3BII, a marker of autophagosomes, could either reflect an increase in autophagy flux, which is somewhat incompatible with the higher p62 and lower Bag3 levels, or reflect an accumulation of autophagosomes that fail to fuse with lysosomes, a known consequence of the missense mutation in HSPB8 [50].
Mutant Hspb8 forms aggregates and causes low autophagy power in the sciatic nerve

Similar to the muscle, we found Hspb8-positive aggregates in symptomatic 18 -month-old $\mathrm{Hspb} 8^{\mathrm{K} 141 \mathrm{~N} / \mathrm{K} 141 \mathrm{~N}}$ mice (Fig. 6b) but not in Hspb8 $8^{\mathrm{K} 141 \mathrm{~N} /+}$ mice (supplementary Fig. S3m) or WT littermates (Fig. 6a). We then measured the amount of proteins involved in Hspb8/Bag3-mediated autophagy in 2-month-old and 12-month-old mice by western blot. The levels of Hspb8 and Bag3 were significantly reduced in the sciatic nerve of 2-month-old $\mathrm{Hspb} 8^{\mathrm{K} 141 \mathrm{~N} / \mathrm{K} 141 \mathrm{~N}}$ mice (Fig. 6c, d). The level of Bag3 was also drastically reduced in 12-month-old $\mathrm{Hspb} 8^{\mathrm{K} 141 \mathrm{~N} / \mathrm{K} 141 \mathrm{~N}}$ mice, whereas Hspb8 protein level was comparable to WT. The levels of p62 were similar to WT both in pre-symptomatic and symptomatic $\mathrm{Hspb} 8^{\mathrm{K} 141 \mathrm{~N} / \mathrm{K} 141 \mathrm{~N}}$ mice. The lipidated form of LC3B could not be detected in sciatic nerve tissue. The absence of detectable LC3BII band was specific to the sciatic nerve, since we could detect it in other tissues from the same animals (Supplementary Fig. S5). We cannot explain this variability in LC3BII detection. One hypothesis could be that the level of autophagy or/and the speed of degradation of autophagosomes (where LC3BII is located) varies among tissues. The affected Hspb8 and Bag 3 protein levels in the absence of p62 and LC3 alteration is reminiscent of the low "autophagy power" pattern described by Crippa et al. in the spinal cord of mutant SOD1 mice [18]. This reduced potential to activate the Hspb8/Bag3-mediated macroautophagy pathway could contribute to the pathogenesis by impairing the degradation of the mutant Hspb8 protein that accumulates and progressively forms insoluble toxic aggregates.

\section{Discussion}

We generated a new transgenic mouse model for the Hspb8 ${ }^{\mathrm{K} 141 \mathrm{~N}}$ mutation causative of dHMN type II, CMT2L, and distal myopathy. The previous transgenic mouse models of mutant Hspb8 have been published [23, 66, 88], but this one is the first with a physiological and ubiquitous expression of the mutant protein. It is the first report of an Hspb8 transgenic mouse line modelling distal myopathy and the faithful reproduction of a human hereditary neuromuscular disease phenotype by a mouse model is actually a rather rare event [6].

It is not entirely clear how independent the neuropathic and myopathic phenotypes are in our Hspb8 $8^{\mathrm{K} 141 \mathrm{~N} / \mathrm{K} 141 \mathrm{~N}}$ mice. The histopathological analysis of the gastrocnemius muscle showing normal fiber type pattern, granulofilamentous material accumulation, Z-disc disorganisation, and cytoskeletal component aggregates points toward a myopathy with myofibrillar component, distinct from a neurogenic muscle 

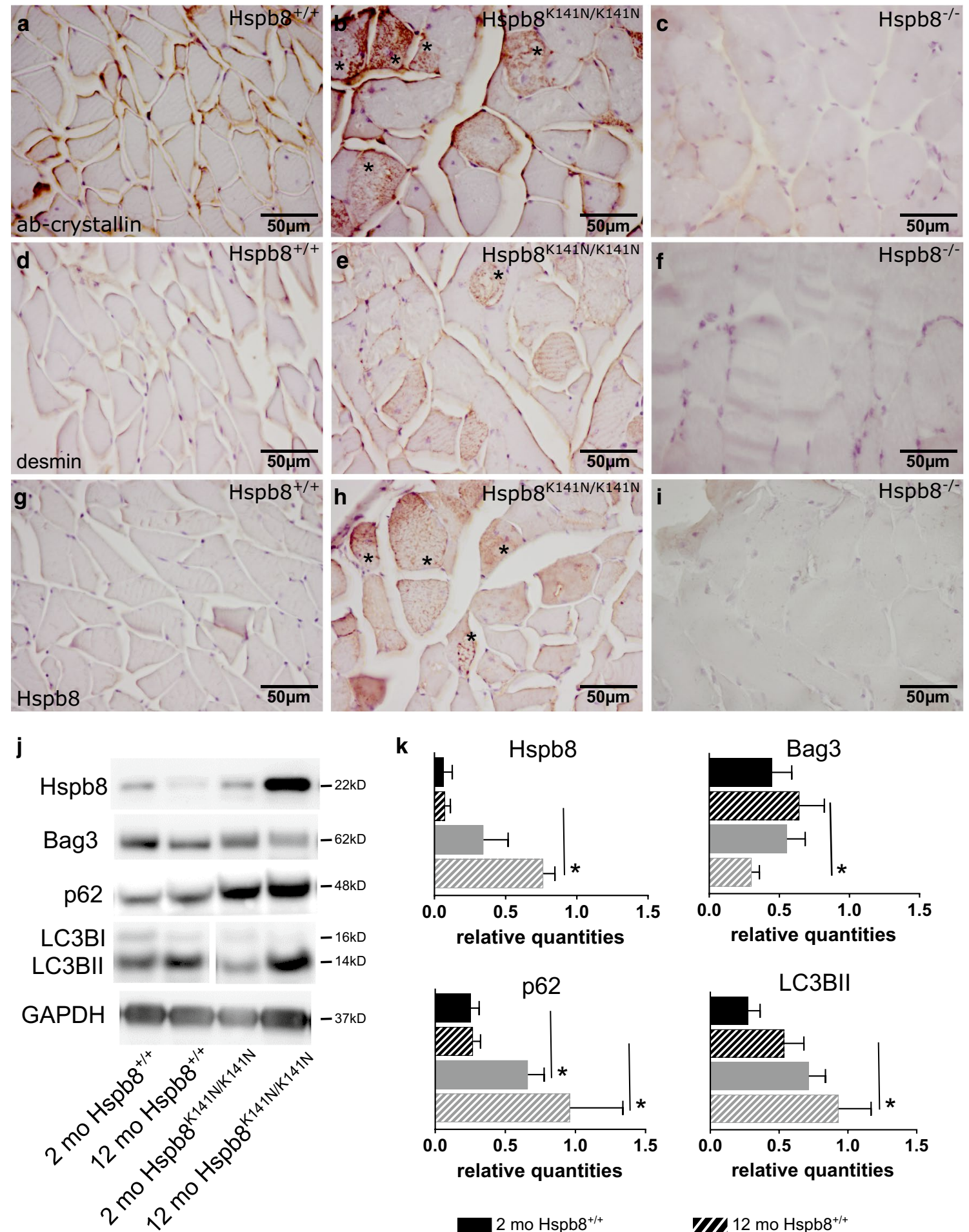

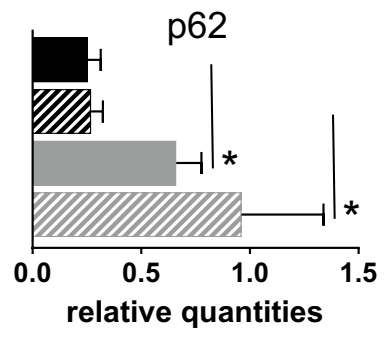

$2 \mathrm{mo} \mathrm{Hspb8}^{+/+}$ 2 mo Hspb8 $8^{\mathrm{K} 141 \mathrm{~N} / \mathrm{K} 141 \mathrm{~N}}$

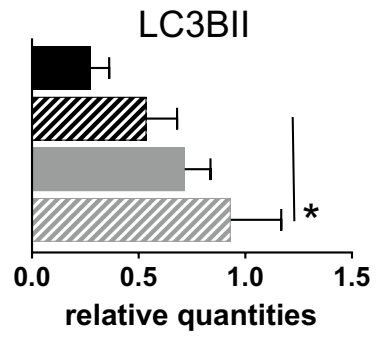

V72 $12 \mathrm{mo} \mathrm{Hspb8}^{+/+}$ VZ12 mo Hspb8 $8^{\mathrm{K} 141 \mathrm{~N} / \mathrm{K} 141 \mathrm{~N}}$
Fig. 5 Aggregates of myofibrillar components and autophagy defects in the muscle of $\mathrm{Hspb} 8^{\mathrm{K} 141 \mathrm{~N} / \mathrm{K} 141 \mathrm{~N}}$ mice. a-c $\alpha \mathrm{B}$-crystallin immunohistochemistry in 12-month-old $\mathrm{Hspb}^{+/+}$(a), $\mathrm{Hspb}^{\mathrm{K} 141 \mathrm{~N} / \mathrm{K} 141 \mathrm{~N}}$ (b) and $\mathrm{Hspb}^{-/-}$(c) mice, with notable dense subsarcolemmal and intermyofibrillar aggregates in $\mathrm{Hspb} 8^{\mathrm{K} 141 \mathrm{~N} / \mathrm{K} 141 \mathrm{~N}}$ mice (b). d, f Desmin immunohistochemistry in 12-month-old $\mathrm{Hspb}^{+/+}(\mathbf{d}), \mathrm{Hspb}^{\mathrm{K} 141 \mathrm{~N} /}$ $\mathrm{K} 141 \mathrm{~N}$ (e) and $\mathrm{Hspb}^{-/-}$(f) mice showing aggregates (asterisk) in some myofibers of $\mathrm{Hspb} 8^{\mathrm{K} 141 \mathrm{~N} / \mathrm{K} 141 \mathrm{~N}}$ mice $(\mathbf{e})$. g, h Hspb8 immu- nohistochemistry in 12-month-old $\mathrm{Hspb}^{+/+}$(g), in 12-month-old $\mathrm{Hspb} 8^{\mathrm{K} 141 \mathrm{~N} / \mathrm{K} 141 \mathrm{~N}}$, showing numerous myofibers containing aggregates (h), and in 12-month-old $\mathrm{Hspb}^{-/-}$(i). j Western blot showing $\mathrm{Hspb} 8$, Bag3, p62, and LC3B in muscle lysates of 2-and 12-monthold $\mathrm{Hspb} 8^{\mathrm{K} 141 \mathrm{~N} / \mathrm{K} 141 \mathrm{~N}}$ and WT mice. GAPDH is used as a loading control. k Quantification of the Hspb8, Bag3, p62, and LC3BII bands normalized on GAPDH. ${ }^{*} p<0.05$. Values are expressed as mean $\pm \mathrm{SD}, N=3$ 


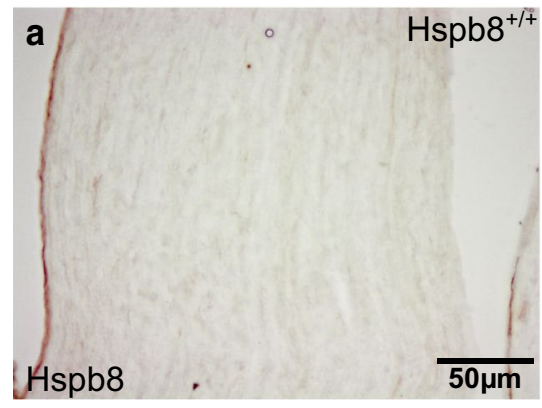

C
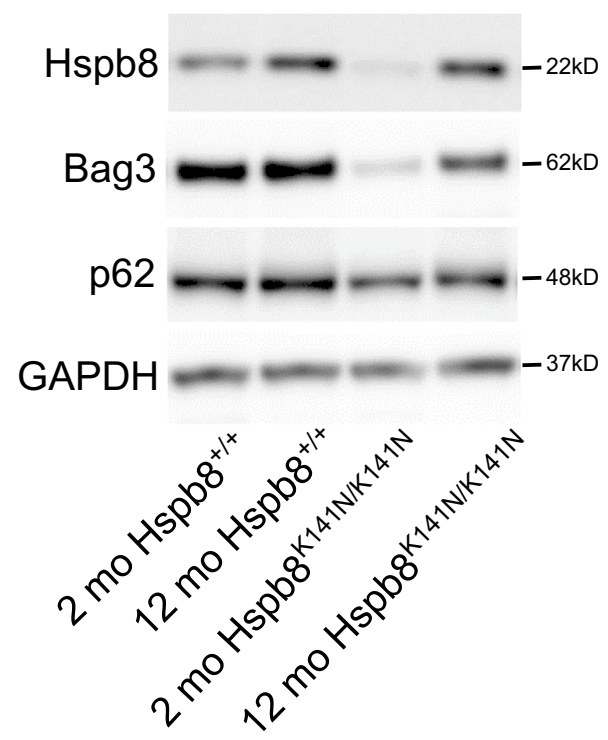

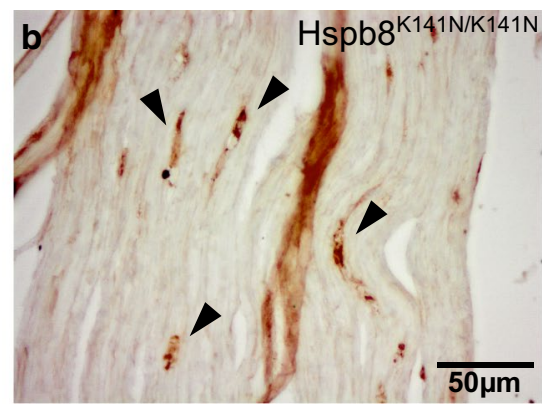

d
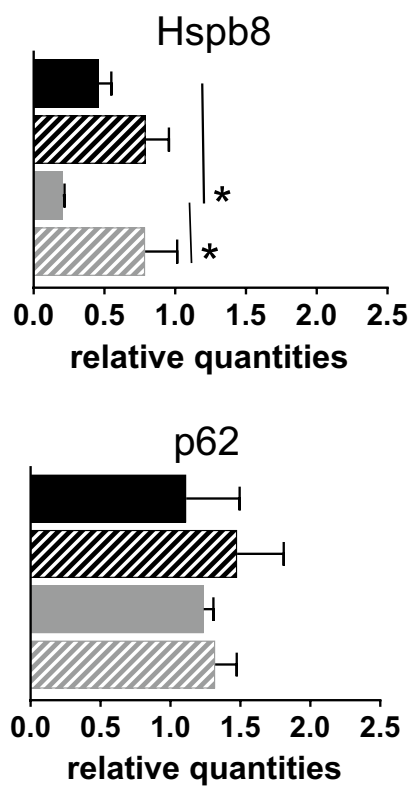
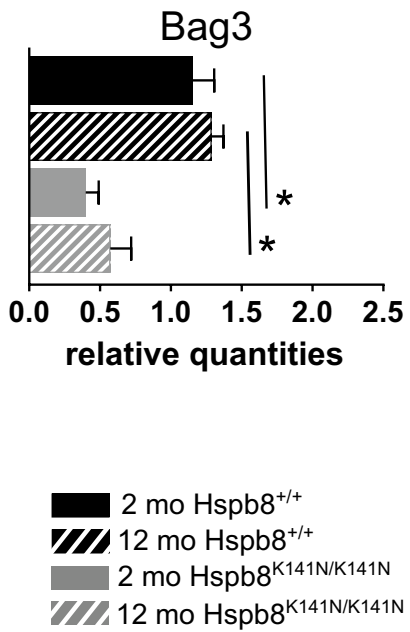

Fig. 6 Hspb8 aggregates and low autophagy power in the sciatic nerve of $\mathrm{Hspb} 8^{\mathrm{K} 141 \mathrm{~N} / \mathrm{K} 141 \mathrm{~N}}$ mice. a, b Hspb8 immunohistochemistry in 18-month-old WT (a) and $\mathrm{Hspb} 8^{\mathrm{K} 141 \mathrm{~N} / \mathrm{K} 141 \mathrm{~N}}$ (b) mice showing that only the Hspb8 $8^{\mathrm{K} 141 \mathrm{~N} / \mathrm{K} 141 \mathrm{~N}}$ mice develop aggregates (b). c Western blot showing Hspb8, Bag3 and p62 and in sciatic nerve lysates

atrophy. On the other hand, the muscle, the nerve, and the motor neurons are the components of the same neuromuscular axis. They are interdependent and are also particularly dependent on a well-functioning proteostatic system. Denervation leads to major changes in proteostasis in the affected muscle fibers, including myofibrillar remodeling and target formation, and induces a dynamic response involving chaperons, endoplasmic reticulum, and autophagy-related proteins [44]. Mutation in these proteins will affect the motor unit's ability to respond to denervation and might trigger a disproportionate "bystander" myopathy. This is supported by the observation that mutations in the same proteins can cause both neuropathies, motor neuron diseases and vacuolar myopathies $[5,25,34,44,45,56,72,76]$.

The heterozygous $\mathrm{Hspb} 8^{\mathrm{K} 141 \mathrm{~N} /+}$ mice, which have an allelic pattern closer to the patient situation, have a much milder phenotype and fail to develop motor deficits. The of 2-and 12-month-old $\mathrm{Hspb} 8^{\mathrm{K} 141 \mathrm{~N} / \mathrm{K} 141 \mathrm{~N}}$ and WT mice. GAPDH is used as a loading control. d Quantification of the Hspb8, Bag3, and p62 bands normalized on GAPDH. $* p<0.05$. Values are expressed as mean $\pm \mathrm{SD}, N=3$

need of a higher expression of the mutant protein to observe a functional phenotype is not peculiar when modelling inherited disease $[7,88]$ and underlines the discrepancies between transgenic mice and human patients, between their respective lifespan, the disease duration, and the complexity of their environment.

Our model allowed the generation of a functional KO line in parallel with the $\mathrm{Hspb} 8^{\mathrm{K} 141 \mathrm{~N}} \mathrm{KI}$ lines. An $\mathrm{Hspb} 8$ KO mouse model has already been developed by others to determine the function of Hspb8 in cardiac tissues, where it is highly expressed [61]. Although that Hspb8 $\mathrm{KO}$ had a normal behaviour and physiology, they showed an increased susceptibility to heart failure under the specific context of cardiac overload [61]. Our Hspb8 KO (Hspb8 $\left.{ }^{-/-}\right)$mice did not develop a neuropathic or myopathic phenotype. The absence of myofiber defect was unexpected, since HSPB8 participates in myofibril stabilisation through the CASA 
complex $[38,79,80]$. Furthermore, depletion of Hspb1, another member of the sHSP family whose mutant form has also been associated with myopathy, leads to myofiber ultrastructural defects [46]. Although the $\mathrm{Hspb} 8^{-/-}$myofibers did not undergo atrophy and degeneration, they presented an accumulation of abnormally patterned mitochondria. Interestingly, comparable structural abnormalities of mitochondria have already been associated with myopathy [57, 83]. This particular susceptibility of mitochondria to Hspb8 deficiency could be attributed to the involvement of Hspb8 in mitochondrial membrane potential maintenance and oxidative phosphorylation $[42,52,62]$. Still, the absence of a phenotype in our KO mice demonstrates that Hspb8 lossof-function is insufficient to produce a strong neuropathic or myopathic phenotype. This implies that a toxic gain-offunction of mutant Hspb8 plays a key role in the pathogenesis of both diseases in our mouse model. However, a recent report describes several patients with an HSPB8 frameshift mutation leading to haploinsufficiency associated with a late (adult) onset myopathy but not with neuropathy [25]. This suggests that some loss-of-function mechanisms also play a role in the development of HSPB8-associated myopathy.

The toxicity of mutant Hspb8 could result from its tendency to accumulate and form large aggregates in the sciatic nerve and myofibers of $\mathrm{Hspb} 8^{\mathrm{K} 141 \mathrm{~N} / \mathrm{K} 141 \mathrm{~N}}$ mice. We have previously shown that mutant $\mathrm{Hspb} 8^{\mathrm{K} 141 \mathrm{~N}}$ is prone to aggregation in patient-derived material [42]. While a few additional studies have associated mutant protein aggregation to axonal neuropathy $[67,78,87]$, there is thus far no clear consensus on how these aggregates contribute to the neurodegeneration. Myofibrillar myopathy (MFM) is also caused by aggregation-prone mutations in proteins associated with the Z-disc $[4,10,53,71]$, including $\alpha \mathrm{B}$-crystallin, SQSTM1, and BAG3, which interact with HSPB8 to mediate chaperone-assisted-selective autophagy (CASA), a process required for the maintenance of myofibrils.

The MFM phenotype associated with BAG3 mutation is thought to result from the progressive accumulation of insoluble BAG3 aggregates and the impairment of the CASA complex to remove these aggregates [49, 64]. In parallel, the neuropathic and myopathic phenotypes in the $\mathrm{Hspb} 8^{\mathrm{K} 141 \mathrm{~N} /}$ $\mathrm{K} 141 \mathrm{~N}$ mice could result from the progressive aggregation of mutant Hspb8 and a reduced ability to remove these aggregates. Indeed, the accumulation of aggregate-prone proteins can be prevented by Hspb8 and Bag3 [12, 16, 20, 21], whose levels are affected in the sciatic nerve of our KI mice. In the muscle, the increase in p62 in post-symptomatic mice suggests a defect in the autophagic flux. The higher levels of LC3BII detected in post-symptomatic $\mathrm{Hspb} 8^{\mathrm{K} 141 \mathrm{~N} / \mathrm{K} 141 \mathrm{~N}}$ mice compared to WT could result from the accumulation of autophagosomes unable to fuse with lysosomes and complete the autophagy flux, since mutant $\mathrm{Hspb} 8^{\mathrm{K} 141 \mathrm{~N}}$ was shown to impair the fusion of autophagosomes with lysosomes [50].

Altogether, our results lead us to conclude that the accumulation of mutant $\mathrm{Hspb} 8^{\mathrm{K} 141 \mathrm{~N}}$ combined with an inability to degrade Hspb8-positive aggregates through Hspb8/ Bag3-mediated autophagy is a key pathomechanism underlying the peripheral neuropathy and distal myopathy in our mouse model. Accumulation of toxic protein clusters within the neuronal soma could be tolerated; however, toxic protein accumulation within the confined long peripheral axons could on long-term disturb axoplasmic flow to the distal axon and synapse. Finally, our study demonstrates that the generation of $\mathrm{KI}$ and $\mathrm{KO}$ mouse lines is a relevant and powerful tool to understand the gain- and loss-of-function mechanisms taking part in the pathogenesis of neuromuscular diseases.

Acknowledgements This work was supported in part by the University of Antwerp, research Grants from the Fund for Scientific Research (FWO-Flanders), the HERCULES foundation for microscopy infrastructure, the "Association Belge contre les Maladies Neuromusculaires"(ABMM), the EU FP7/2007_2013 under grant agreement number 2012-305121 (NEUROMICS), the Medical Foundation Queen Elisabeth (GSKE), the American Muscular Dystrophy Association (MDA; Grant 3962), and by a grant from the German Ministry of Education and Research (BMBF; Grant 01GM1511D) to JW and IK. AH received a PhD fellowship from the Institute of Science and Technology (IWT), Belgium. DB and JI obtained postdoctoral fellowships from the FWO. We acknowledge Prof. Dr. A. Poletti, Prof. Dr. S. Carra, and Dr. A. Goswami for their generous advices and their precious comments on our results.

\section{Compliance with ethical standards}

Conflict of interest The authors declare that they do not have any competing or financial interests.

Open Access This article is distributed under the terms of the Creative Commons Attribution 4.0 International License (http://creativecommons.org/licenses/by/4.0/), which permits unrestricted use, distribution, and reproduction in any medium, provided you give appropriate credit to the original author(s) and the source, provide a link to the Creative Commons license, and indicate if changes were made.

\section{References}

1. Almeida-Souza L, Asselbergh B, d'Ydewalle C, Moonens K, Goethals S, De Winter V, Azmi A, Irobi J, Timmermans JP, Gevaert K et al (2011) Small heat-shock protein HSPB1 mutants stabilize microtubules in Charcot-Marie-Tooth neuropathy. J Neurosci 31:15320-15328. doi:10.1523/JNEUROSCI.3266-11.2011

2. Arndt V, Dick N, Tawo R, Dreiseidler M, Wenzel D, Hesse M, Furst DO, Saftig P, Saint R, Fleischmann BK et al (2010) Chaperone-assisted selective autophagy is essential for muscle maintenance. Curr Biol 20:143-148. doi:10.1016/j.cub.2009.11.022

3. Arrigo AP (2001) Hsp27: novel regulator of intracellular redox state. IUBMB Life 52:303-307. doi:10.1080/152165401317291165 
4. Avila-Smirnow D, Gueneau L, Batonnet-Pichon S, Delort F, Becane HM, Claeys K, Beuvin M, Goudeau B, Jais JP, Nelson I et al (2016) Cardiac arrhythmia and late-onset muscle weakness caused by a myofibrillar myopathy with unusual histopathological features due to a novel missense mutation in FLNC. Rev Neurol (Paris) 172:594-606. doi:10.1016/j.neurol.2016.07.017

5. Ayaki T, Ito H, Fukushima H, Inoue T, Kondo T, Ikemoto A, Asano T, Shodai A, Fujita T, Fukui S et al (2014) Immunoreactivity of valosin-containing protein in sporadic amyotrophic lateral sclerosis and in a case of its novel mutant. Acta Neuropathol Commun 2:172. doi:10.1186/s40478-014-0172-0

6. Batonnet-Pichon S, Behin A, Cabet E, Delort F, Vicart P, Lilienbaum A (2017) Myofibrillar myopathies: new perspectives from animal models to potential therapeutic approaches. J Neuromuscul Dis 4:1-15. doi:10.3233/JND-160203

7. Bouhy D, Geuens T, De Winter V, Almeida-Souza L, Katona I, Weis J, Hochepied T, Goossens S, Haigh JJ, Janssens S et al (2016) Characterization of new transgenic mouse models for two Charcot-Marie-Tooth-Causing HspB1 mutations using the Rosa26 locus. J Neuromuscul Dis 3:183-200. doi:10.3233/JND-150144

8. Bouhy D, Malgrange B, Multon S, Poirrier AL, Scholtes F, Schoenen J, Franzen R (2006) Delayed GM-CSF treatment stimulates axonal regeneration and functional recovery in paraplegic rats via an increased BDNF expression by endogenous macrophages. FASEB J 20:1239-1241. doi:10.1096/fj.05-4382fje

9. Bremer J, Baumann F, Tiberi C, Wessig C, Fischer H, Schwarz P, Steele AD, Toyka KV, Nave KA, Weis J et al (2010) Axonal prion protein is required for peripheral myelin maintenance. Nat Neurosci 13:310-318. doi:10.1038/nn.2483

10. Bucelli RC, Arhzaouy K, Pestronk A, Pittman SK, Rojas L, Sue CM, Evila A, Hackman P, Udd B, Harms MB et al (2015) SQSTM1 splice site mutation in distal myopathy with rimmed vacuoles. Neurology 85:665-674. doi:10.1212/ WNL.0000000000001864

11. Capponi S, Geroldi A, Fossa P, Grandis M, Ciotti P, Gulli R, Schenone A, Mandich P, Bellone E (2011) HSPB1 and HSPB8 in inherited neuropathies: study of an Italian cohort of dHMN and CMT2 patients. J Peripher Nerv Syst 16:287-294. doi:10.1111/j.1529-8027.2011.00361.x

12. Carra S, Boncoraglio A, Kanon B, Brunsting JF, Minoia M, Rana A, Vos MJ, Seidel K, Sibon OC, Kampinga HH (2010) Identification of the Drosophila ortholog of HSPB8: implication of HSPB8 loss of function in protein folding diseases. J Biol Chem 285:37811-37822. doi:10.1074/jbc.M110.127498

13. Carra S, Brunsting JF, Lambert H, Landry J, Kampinga HH (2009) HspB8 participates in protein quality control by a non-chaperonelike mechanism that requires eIF2 \{alpha\} phosphorylation. J Biol Chem 284:5523-5532. doi:10.1074/jbc.M807440200

14. Carra S, Seguin SJ, Lambert H, Landry J (2008) HspB8 chaperone activity toward poly $(\mathrm{Q})$-containing proteins depends on its association with Bag3, a stimulator of macroautophagy. J Biol Chem 283:1437-1444. doi:10.1074/jbc.M706304200

15. Carra S, Seguin SJ, Landry J (2008) HspB8 and Bag3: a new chaperone complex targeting misfolded proteins to macroautophagy. Autophagy 4:237-239

16. Carra S, Sivilotti M, Chavez Zobel AT, Lambert H, Landry J (2005) HspB8, a small heat shock protein mutated in human neuromuscular disorders, has in vivo chaperone activity in cultured cells. Hum Mol Genet 14:1659-1669. doi:10.1093/hmg/ddi174

17. Claeys KG, Fardeau M, Schroder R, Suominen T, Tolksdorf K, Behin A, Dubourg O, Eymard B, Maisonobe T, Stojkovic T et al (2008) Electron microscopy in myofibrillar myopathies reveals clues to the mutated gene. Neuromuscul Disord 18:656-666. doi:10.1016/j.nmd.2008.06.367

18. Crippa V, Boncoraglio A, Galbiati M, Aggarwal T, Rusmini P, Giorgetti E, Cristofani R, Carra S, Pennuto M, Poletti A (2013)
Differential autophagy power in the spinal cord and muscle of transgenic ALS mice. Front Cell Neurosci 7:234. doi:10.3389/ fncel.2013.00234

19. Crippa V, Carra S, Rusmini P, Sau D, Bolzoni E, Bendotti C, De Biasi S, Poletti A (2010) A role of small heat shock protein B8 (HspB8) in the autophagic removal of misfolded proteins responsible for neurodegenerative diseases. Autophagy 6:958-960. doi:10.4161/auto.6.7.13042

20. Crippa V, Cicardi ME, Ramesh N, Seguin SJ, Ganassi M, Bigi I, Diacci C, Zelotti E, Baratashvili M, Gregory JM et al (2016) The chaperone HSPB8 reduces the accumulation of truncated TDP-43 species in cells and protects against TDP-43-mediated toxicity. Hum Mol Genet 25:3908-3924. doi:10.1093/hmg/ddw232

21. Crippa V, D’Agostino VG, Cristofani R, Rusmini P, Cicardi ME, Messi E, Loffredo R, Pancher M, Piccolella M, Galbiati M et al (2016) Transcriptional induction of the heat shock protein B8 mediates the clearance of misfolded proteins responsible for motor neuron diseases. Sci Rep 6:22827. doi:10.1038/srep22827

22. Crippa V, Sau D, Rusmini P, Boncoraglio A, Onesto E, Bolzoni E, Galbiati M, Fontana E, Marino M, Carra S et al (2010) The small heat shock protein B8 (HspB8) promotes autophagic removal of misfolded proteins involved in amyotrophic lateral sclerosis (ALS). Hum Mol Genet 19:3440-3456. doi:10.1093/ hmg/ddq257

23. Depre C, Hase M, Gaussin V, Zajac A, Wang L, Hittinger L, Ghaleh B, Yu X, Kudej RK, Wagner T et al (2002) H11 kinase is a novel mediator of myocardial hypertrophy in vivo. Circ Res 91:1007-1014. doi:10.1161/01.RES.0000044380.54896.4B

24. Echaniz-Laguna A, Geuens T, Petiot P, Pereon Y, Adriaenssens E, Haidar M, Capponi S, Maisonobe T, Fournier E, Dubourg O et al (2017) Axonal neuropathies due to mutations in small heat shock proteins: clinical, genetic, and functional insights into novel mutations. Hum Mutat. doi:10.1002/humu.23189

25. Echaniz-Laguna A, Lornage X, Lannes B, Schneider R, Bierry G, Dondaine N, Boland A, Deleuze JF, Bohm J, Thompson J et al (2017) HSPB8 haploinsufficiency causes dominant adultonset axial and distal myopathy. Acta Neuropathol 134:163-165. doi:10.1007/s00401-017-1724-8

26. Elbracht M, Senderek J, Schara U, Nolte K, Klopstock T, Roos A, Reimann J, Zerres K, Weis J, Rudnik-Schoneborn S (2014) Clinical and morphological variability of the E396K mutation in the neurofilament light chain gene in patients with CharcotMarie- Tooth disease type 2E. Clin Neuropathol 33:335-343. doi:10.5414/NP300742

27. Evgrafov OV, Mersiyanova I, Irobi J, Van Den Bosch L, Dierick I, Leung CL, Schagina O, Verpoorten N, Van Impe K, Fedotov $\mathrm{V}$ et al (2004) Mutant small heat-shock protein 27 causes axonal Charcot-Marie-Tooth disease and distal hereditary motor neuropathy. Nat Genet 36:602-606. doi:10.1038/ng1354

28. Fichna JP, Potulska-Chromik A, Miszta P, Redowicz MJ, Kaminska AM, Zekanowski C, Filipek S (2017) A novel dominant D109A CRYAB mutation in a family with myofibrillar myopathy affects alphaB-crystallin structure. BBA Clin 7:1-7. doi:10.1016/j. bbacli.2016.11.004

29. Fontaine JM, Sun X, Hoppe AD, Simon S, Vicart P, Welsh MJ, Benndorf R (2006) Abnormal small heat shock protein interactions involving neuropathy-associated HSP22 (HSPB8) mutants. FASEB J 20:2168-2170. doi:10.1096/fj.06-5911fje

30. Fuchs M, Luthold C, Guilbert SM, Varlet AA, Lambert H, Jette A, Elowe S, Landry J, Lavoie JN (2015) A role for the chaperone complex BAG3-HSPB8 in actin dynamics, spindle orientation and proper chromosome segregation during mitosis. PLoS Genet 11:e1005582. doi:10.1371/journal.pgen.1005582

31. Ganassi M, Mateju D, Bigi I, Mediani L, Poser I, Lee HO, Seguin SJ, Morelli FF, Vinet J, Leo G et al (2016) A surveillance function of the HSPB8-BAG3-HSP70 chaperone complex ensures 
stress granule integrity and dynamism. Mol Cell 63:796-810. doi:10.1016/j.molcel.2016.07.021

32. George SH, Gertsenstein M, Vintersten K, Korets-Smith E, Murphy J, Stevens ME, Haigh JJ, Nagy A (2007) Developmental and adult phenotyping directly from mutant embryonic stem cells. Proc Natl Acad Sci USA 104:4455-4460. doi:10.1073/ pnas.0609277104

33. Geuens T, De Winter V, Rajan N, Achsel T, Mateiu L, AlmeidaSouza L, Asselbergh B, Bouhy D, Auer-Grumbach M, Bagni C et al (2017) Mutant HSPB1 causes loss of translational repression by binding to PCBP1, an RNA binding protein with a possible role in neurodegenerative disease. Acta Neuropathol Commun 5:5. doi:10.1186/s40478-016-0407-3

34. Ghaoui R, Palmio J, Brewer J, Lek M, Needham M, Evila A, Hackman P, Jonson PH, Penttila S, Vihola A et al (2016) Mutations in HSPB8 causing a new phenotype of distal myopathy and motor neuropathy. Neurology 86:391-398. doi:10.1212/ WNL.0000000000002324

35. Harding AE, Thomas PK (1980) Hereditary distal spinal muscular atrophy. A report on 34 cases and a review of the literature. $\mathrm{J}$ Neurol Sci 45:337-348

36. Haslbeck M, Franzmann T, Weinfurtner D, Buchner J (2005) Some like it hot: the structure and function of small heat-shock proteins. Nat Struct Mol Biol 12:842-846. doi:10.1038/nsmb993

37. Hellemans J, Mortier G, De Paepe A, Speleman F, Vandesompele J (2007) qBase relative quantification framework and software for management and automated analysis of real-time quantitative PCR data. Genome Biol 8:R19. doi:10.1186/gb-2007-8-2-r19

38. Hishiya A, Kitazawa T, Takayama S (2010) BAG3 and Hsc70 interact with actin capping protein CapZ to maintain myofibrillar integrity under mechanical stress. Circ Res 107:1220-1231. doi:10.1161/CIRCRESAHA.110.225649

39. Holmgren A, Bouhy D, De Winter V, Asselbergh B, Timmermans JP, Irobi J, Timmerman V (2013) Charcot-Marie-Tooth causing HSPB 1 mutations increase Cdk5-mediated phosphorylation of neurofilaments. Acta Neuropathol 126:93-108. doi:10.1007/ s00401-013-1133-6

40. Homma S, Iwasaki M, Shelton GD, Engvall E, Reed JC, Takayama S (2006) BAG3 deficiency results in fulminant myopathy and early lethality. Am J Pathol 169:761-773. doi:10.2353/ ajpath.2006.060250

41. Irobi J, Almeida-Souza L, Asselbergh B, De Winter V, Goethals S, Dierick I, Krishnan J, Timmermans JP, Robberecht W, De Jonghe $P$ et al (2010) Mutant HSPB8 causes motor neuron-specific neurite degeneration. Hum Mol Genet 19:3254-3265. doi:10.1093/ $\mathrm{hmg} / \mathrm{ddq} 234$

42. Irobi J, Holmgren A, De Winter V, Asselbergh B, Gettemans J, Adriaensen D, Ceuterick-de Groote C, Van Coster R, De Jonghe P, Timmerman V (2012) Mutant HSPB8 causes protein aggregates and a reduced mitochondrial membrane potential in dermal fibroblasts from distal hereditary motor neuropathy patients. Neuromuscul Disord 22:699-711. doi:10.1016/j.nmd.2012.04.005

43. Irobi J, Van Impe K, Seeman P, Jordanova A, Dierick I, Verpoorten N, Michalik A, De Vriendt E, Jacobs A, Van Gerwen V et al (2004) Hot-spot residue in small heat-shock protein 22 causes distal motor neuropathy. Nat Genet 36:597-601. doi:10.1038/ ng 1328

44. Jesse CM, Bushuven E, Tripathi P, Chandrasekar A, Simon CM, Drepper C, Yamoah A, Dreser A, Katona I, Johann S et al (2016) ALS-associated endoplasmic reticulum proteins in denervated skeletal muscle: implications for motor neuron disease pathology. Brain Pathol. doi:10.1111/bpa.12453

45. Johnson JO, Pioro EP, Boehringer A, Chia R, Feit H, Renton AE, Pliner HA, Abramzon Y, Marangi G, Winborn BJ et al (2014) Mutations in the Matrin 3 gene cause familial amyotrophic lateral sclerosis. Nat Neurosci 17:664-666. doi:10.1038/nn.3688
46. Kammoun M, Picard B, Astruc T, Gagaoua M, Aubert D, Bonnet M, Blanquet V, Cassar-Malek I (2016) The invalidation of HspB1 gene in mouse alters the ultrastructural phenotype of muscles. PLoS One 11:e0158644. doi:10.1371/journal.pone.0158644

47. Kley RA, Olive M, Schroder R (2016) New aspects of myofibrillar myopathies. Curr Opin Neurol 29:628-634. doi:10.1097/ WCO.0000000000000357

48. Kolb SJ, Snyder PJ, Poi EJ, Renard EA, Bartlett A, Gu S, Sutton S, Arnold WD, Freimer ML, Lawson VH et al (2010) Mutant small heat shock protein B3 causes motor neuropathy: utility of a candidate gene approach. Neurology 74:502-506. doi:10.1212/WNL.0b013e3181cef84a

49. Konersman CG, Bordini BJ, Scharer G, Lawlor MW, Zangwill S, Southern JF, Amos L, Geddes GC, Kliegman R, Collins MP (2015) BAG3 myofibrillar myopathy presenting with cardiomyopathy. Neuromuscul Disord 25:418-422. doi:10.1016/j. nmd.2015.01.009

50. Kwok AS, Phadwal K, Turner BJ, Oliver PL, Raw A, Simon AK, Talbot K, Agashe VR (2011) HspB8 mutation causing hereditary distal motor neuropathy impairs lysosomal delivery of autophagosomes. J Neurochem 119:1155-1161. doi:10.1111/j.1471-4159.2011.07521.x

51. Lakso M, Sauer B, Mosinger B Jr, Lee EJ, Manning RW, Yu SH, Mulder KL, Westphal H (1992) Targeted oncogene activation by site-specific recombination in transgenic mice. Proc Natl Acad Sci USA 89:6232-6236

52. Laure L, Long R, Lizano P, Zini R, Berdeaux A, Depre C, Morin D (2012) Cardiac H11 kinase/Hsp22 stimulates oxidative phosphorylation and modulates mitochondrial reactive oxygen species production: involvement of a nitric oxide-dependent mechanism. Free Radic Biol Med 52:2168-2176. doi:10.1016/j. freeradbiomed.2012.03.001

53. Mitzelfelt KA, Limphong P, Choi MJ, Kondrat FD, Lai S, Kolander KD, Kwok WM, Dai Q, Grzybowski MN, Zhang H et al (2016) The human 343delT HSPB5 chaperone associated with early-onset skeletal myopathy causes defects in protein solubility. J Biol Chem 291:14939-14953. doi:10.1074/jbc. M116.730481

54. Morrow G, Le Pecheur M, Tanguay RM (2016) Drosophila melanogaster mitochondrial Hsp22: a role in resistance to oxidative stress, aging and the mitochondrial unfolding protein response. Biogerontology 17:61-70. doi:10.1007/s10522-015-9591-y

55. Nakhro K, Park JM, Kim YJ, Yoon BR, Yoo JH, Koo H, Choi BO, Chung KW (2013) A novel Lys141Thr mutation in small heat shock protein 22 (HSPB8) gene in Charcot-Marie-Tooth disease type 2L. Neuromuscul Disord 23:656-663. doi:10.1016/j. nmd.2013.05.009

56. Nishimura AL, Mitne-Neto M, Silva HC, Richieri-Costa A, Middleton S, Cascio D, Kok F, Oliveira JR, Gillingwater $\mathrm{T}$, Webb J et al (2004) A mutation in the vesicle-trafficking protein VAPB causes late-onset spinal muscular atrophy and amyotrophic lateral sclerosis. Am J Hum Genet 75:822-831. doi:10.1086/425287

57. Papanicolaou KN, Kikuchi R, Ngoh GA, Coughlan KA, Dominguez I, Stanley WC, Walsh K (2012) Mitofusins 1 and 2 are essential for postnatal metabolic remodeling in heart. Circ Res 111:1012-1026. doi:10.1161/CIRCRESAHA.112.274142

58. Phadke R, Rossor A, Benoy V, Kalmar B, King R, Greensmith L, Bosch L, Reilly M, Houlden H (2015) Neuropathological findings from a human post mortem case of distal hereditary motor neuropathy (dHMN) due to p.Ser135Phe HSPB1 mutation and transgenic mice with mutant or wild-type HSP27 overexpression. Neuromuscul Disord 25:S283-S283. doi:10.1016/j.nmd.2015.06.348

59. Piccolella M, Crippa V, Cristofani R, Rusmini P, Galbiati M, Cicardi ME, Meroni M, Ferri N, Morelli FF, Carra S et al (2017) The small heat shock protein B8 (HSPB8) modulates proliferation 
and migration of breast cancer cells. Oncotarget 8:10400-10415. doi:10.18632/oncotarget.14422

60. Preibisch S, Saalfeld S, Tomancak P (2009) Globally optimal stitching of tiled 3D microscopic image acquisitions. Bioinformatics 25:1463-1465. doi:10.1093/bioinformatics/btp184

61. Qiu H, Lizano P, Laure L, Sui X, Rashed E, Park JY, Hong C, Gao S, Holle E, Morin D et al (2011) H11 kinase/heat shock protein 22 deletion impairs both nuclear and mitochondrial functions of STAT3 and accelerates the transition into heart failure on cardiac overload. Circulation 124:406-415. doi:10.1161/ CIRCULATIONAHA.110.013847

62. Rashed E, Lizano P, Dai H, Thomas A, Suzuki CK, Depre C, Qiu H (2015) Heat shock protein 22 (Hsp22) regulates oxidative phosphorylation upon its mitochondrial translocation with the inducible nitric oxide synthase in mammalian heart. PLoS One 10:e0119537. doi:10.1371/journal.pone.0119537

63. Rossor AM, Davidson GL, Blake J, Polke JM, Murphy SM, Houlden H, Innes A, Kalmar B, Greensmith L, Reilly MM (2012) A novel p.Gln $175 X$ [corrected] premature stop mutation in the C-terminal end of HSP27 is a cause of CMT2. J Peripher Nerv Syst 17:201-205. doi:10.1111/j.1529-8027.2012.00400.x

64. Ruparelia AA, Oorschot V, Vaz R, Ramm G, Bryson-Richardson RJ (2014) Zebrafish models of BAG3 myofibrillar myopathy suggest a toxic gain of function leading to BAG3 insufficiency. Acta Neuropathol 128:821-833. doi:10.1007/s00401-014-1344-5

65. Rusmini P, Crippa V, Cristofani R, Rinaldi C, Cicardi ME, Galbiati M, Carra S, Malik B, Greensmith L, Poletti A (2016) The role of the protein quality control system in SBMA. J Mol Neurosci 58:348-364. doi:10.1007/s12031-015-0675-6

66. Sanbe A, Marunouchi T, Abe T, Tezuka Y, Okada M, Aoki S, Tsumura H, Yamauchi J, Tanonaka K, Nishigori H et al (2013) Phenotype of cardiomyopathy in cardiac-specific heat shock protein B8 K141N transgenic mouse. J Biol Chem 288:8910-8921. doi:10.1074/jbc.M112.368324

67. Sasaki T, Gotow T, Shiozaki M, Sakaue F, Saito T, Julien JP, Uchiyama Y, Hisanaga S (2006) Aggregate formation and phosphorylation of neurofilament-L Pro22 Charcot-Marie-Tooth disease mutants. Hum Mol Genet 15:943-952. doi:10.1093/hmg/ dd 1011

68. Scarlato M, Vigano F, Carrera P, Previtali SC, Bolino A (2015) A novel heat shock protein 27 homozygous mutation: widening of the continuum between MND/dHMN/CMT2. J Peripher Nerv Syst 20:419-421. doi:10.1111/jns. 12139

69. Schindelin J, Arganda-Carreras I, Frise E, Kaynig V, Longair M, Pietzsch T, Preibisch S, Rueden C, Saalfeld S, Schmid B et al (2012) Fiji: an open-source platform for biological-image analysis. Nat Methods 9:676-682. doi:10.1038/nmeth.2019

70. Schneider CA, Rasband WS, Eliceiri KW (2012) NIH Image to ImageJ: 25 years of image analysis. Nat Methods 9:671-675

71. Selcen D, Muntoni F, Burton BK, Pegoraro E, Sewry C, Bite AV, Engel AG (2009) Mutation in BAG3 causes severe dominant childhood muscular dystrophy. Ann Neurol 65:83-89. doi:10.1002/ana.21553

72. Shen H, Barry DM, Dale JM, Garcia VB, Calcutt NA, Garcia ML (2011) Muscle pathology without severe nerve pathology in a new mouse model of Charcot-Marie-Tooth disease type 2E. Hum Mol Genet 20:2535-2548. doi:10.1093/hmg/ddr152

73. Sun X, Fontaine JM, Hoppe AD, Carra S, DeGuzman C, Martin JL, Simon S, Vicart P, Welsh MJ, Landry J et al (2010) Abnormal interaction of motor neuropathy-associated mutant HspB8 (Hsp22) forms with the RNA helicase Ddx20 (gemin3). Cell Stress Chaperones 15:567-582. doi:10.1007/s12192-010-0169-y

74. Tang BS, Zhao GH, Luo W, Xia K, Cai F, Pan Q, Zhang RX, Zhang FF, Liu XM, Chen B et al (2005) Small heat-shock protein 22 mutated in autosomal dominant Charcot-MarieTooth disease type 2L. Hum Genet 116:222-224. doi:10.1007/ s00439-004-1218-3

75. Timmerman V, Beuten J, Irobi J, De Jonghe P, Martin JJ, Van Broeckhoven C (1999) Distal hereditary motor neuropathy type II (distal HMN type II): phenotype and molecular genetics. Ann N Y Acad Sci 883:60-64

76. Timmerman V, De Jonghe P, Simokovic S, Lofgren A, Beuten J, Nelis E, Ceuterick C, Martin JJ, Van Broeckhoven C (1996) Distal hereditary motor neuropathy type II (distal HMN II): mapping of a locus to chromosome 12q24. Hum Mol Genet 5:1065-1069

77. Timmerman V, Raeymaekers P, Nelis E, De Jonghe P, Muylle L, Ceuterick C, Martin JJ, Van Broeckhoven C (1992) Linkage analysis of distal hereditary motor neuropathy type II (distal HMN II) in a single pedigree. J Neurol Sci 109:41-48

78. Tsai PC, Huang YH, Guo YC, Wu HT, Lin KP, Tsai YS, Liao YC, Liu YT, Liu TT, Kao LS et al (2014) A novel TFG mutation causes Charcot-Marie-Tooth disease type 2 and impairs TFG function. Neurology 83:903-912. doi:10.1212/WNL.0000000000000758

79. Ulbricht A, Arndt V, Hohfeld J (2013) Chaperone-assisted proteostasis is essential for mechanotransduction in mammalian cells. Commun Integr Biol 6:e24925. doi:10.4161/cib.24925

80. Ulbricht A, Gehlert S, Leciejewski B, Schiffer T, Bloch W, Hohfeld J (2015) Induction and adaptation of chaperone-assisted selective autophagy CASA in response to resistance exercise in human skeletal muscle. Autophagy 11:538-546. doi:10.1080/15 548627.2015.1017186

81. Varlet AA, Fuchs M, Luthold C, Lambert H, Landry J, Lavoie JN (2017) Fine-tuning of actin dynamics by the HSPB8-BAG3 chaperone complex facilitates cytokinesis and contributes to its impact on cell division. Cell Stress Chaperones. doi:10.1007/ s12192-017-0780-2

82. Vicart P, Caron A, Guicheney P, Li Z, Prevost MC, Faure A, Chateau D, Chapon F, Tome F, Dupret JM et al (1998) A missense mutation in the alphaB-crystallin chaperone gene causes a desmin-related myopathy. Nat Genet 20:92-95. doi:10.1038/1765

83. Vincent AE, Ng YS, White K, Davey T, Mannella C, Falkous G, Feeney C, Schaefer AM, McFarland R, Gorman GS et al (2016) The spectrum of mitochondrial ultrastructural defects in mitochondrial myopathy. Sci Rep 6:30610. doi:10.1038/srep30610

84. Weis J, Claeys KG, Roos A, Azzedine H, Katona I, Schroder JM, Senderek J (2016) Towards a functional pathology of hereditary neuropathies. Acta Neuropathol. doi:10.1007/s00401-016-1645-y

85. Ydens E, Demon D, Lornet G, De Winter V, Timmerman V, Lamkanfi M, Janssens S (2015) Nlrp6 promotes recovery after peripheral nerve injury independently of inflammasomes. J Neuroinflammation 12:143. doi:10.1186/s12974-015-0367-8

86. Ye H, Huang H, Cao F, Chen M, Zheng X, Zhan R (2016) HSPB1 enhances SIRT2-mediated G6PD activation and promotes glioma cell proliferation. PLoS One 11:e0164285. doi:10.1371/journal. pone. 0164285

87. Zhai J, Lin H, Julien JP, Schlaepfer WW (2007) Disruption of neurofilament network with aggregation of light neurofilament protein: a common pathway leading to motor neuron degeneration due to Charcot-Marie-Tooth disease-linked mutations in NFL and HSPB1. Hum Mol Genet 16:3103-3116. doi:10.1093/hmg/ ddm 272

88. Zhang R, Zhang F, Li X, Huang S, Zi X, Liu T, Liu S, Li X, Xia K, Pan Q et al (2014) A novel transgenic mouse model of Chinese Charcot-Marie-Tooth disease type 2L. Neural Regen Res 9:413-419. doi:10.4103/1673-5374.128248 